\title{
The New Era of Digital Transformation and COVID-19 Effect on The Employment in Mobile Operators in Egypt
}

\author{
Ashraf Elsafty ${ }^{1} \&$ Ahmed Elzeftawy $^{1}$ \\ ${ }^{1}$ Adjunct Assistant Professor, Maastricht School of Management, Cairo Outreach, Egypt \\ ${ }^{1}$ DBA Candidate, University of Business and International Studies, UBIS, Brilliance-Cairo Outreach, Egypt \\ Correspondence: Ashraf Elsafty, Adjunct Assistant Professor, Maastricht School of Management, Cairo Outreach, \\ Egypt. ORCID ID: https://orcid.org/0000-0002-9377-7286
}

Received: January 28, 2021

doi:10.11114/bms.v7i1.5145
Accepted: February 8, 2021

Online Published: February 24, 2021

URL: https://doi.org/10.11114/bms.v7i1.5145

\begin{abstract}
A fear from Technological Advances mainly automation and artificial intelligence (AI) has been raised since the beginning of the $21^{\text {st }}$ century, that machines will eliminate human beings performing certain tasks. Several models were developed to measure the effect of the Automation \& AI on the employment and was applied on several countries. The first model was developed by Carl Benedikt Frey and Michael A. Osborne was called An Occupation-Based Approach, 2013. In which they define several tasks and call it "Engineering-Bottlenecks". Katharina Dengler, Britta Matthes and Wiebke Paulus, 2014 made The Occupational Tasks model in which they use the assignment of activities explained by Alexandra Spitz-Oener and categorize the non-automatable tasks as: analytical non-routine tasks, interactive non-routine tasks. The last model was A-Task Based Approach by Melanie Arntz, Terry Gregory, 2016 in which they argue that FO Model Ignore that, the occupations consist of many tasks, part of them can be automated and another part cannot be. These models were applied on the level of the countries but not on corporate levels.
\end{abstract}

The purpose of this paper is to combine the above three models and applying them on the Mobile operators in Egypt to determine the effect of Automation and AI on the Employment there, taking into consideration the incremental risk from COVID-19 which influenced the humanity.

The conclusion of this research is that $41 \%$ of the staff working in the Technology field on the mobile operators, their jobs are subject to automation and COVID-19 will make an incremental Risk of $8 \%$, due to creation of efficiency on performing the un-automatable tasks from home through digital platforms.

Keywords: Unemployment, Automation, Artificial Intelligent, Digital Transformation, COVID-19

\section{Introduction}

A fear from technological advancement has been escalated in the last two centuries in which many middle-class Tasks can be automated (Autor, 2015). Machines can perform a whole occupations tasks or several tasks from it, eliminating/reducing the workers performing a certain jobs (Bessen, 2016). Because of the increased computing power and the technological advances in Artificial intelligence, the history experience of previous industrial revolutions cannot predict the future of jobs in which robotics which can replace the labors in jobs was never expected to be automated (Autor, 2015). Several scientists stud these phenomena and producing models which calculate the potential risk on several countries. The most famous models were: The Task Model, 2003 produced by David H. Autor, Frank Levy, and Richard J. Murnane, in which they argue that computers can perform only Routine tasks (Autor, Levy, \& Murnane, 2003). An Occupation-Based Approach, 2013 produced by Carl Benedikt Frey and Michael A. Osborne, in which they modify the previous model by adding more tasks that computer can do using AI and exclude other tasks in which they call it "Engineering-Bottlenecks". The model was applied on USA reveal that $47 \%$ of American employees are at high risk of automation. Several studies were applied in other countries using this methodology indicate that Automation Risk in EU Market is 14\% (Pouliakas, 2018), Spain 36\% (Doménech, García, Montañez, \& Neut, 2017). Finland 33\% (Pajarinen \& Rouvinen, 2014), Singapore 25\% (Fuei, 2017). Another model was The Occupational Tasks in the German Labour Market by Katharina Dengler, Britta Matthes and Wiebke Paulus, 2014 in which they use the assignment of activities explained by Alexandra Spitz-Oener in which they applying it on BERUFENET Database (belongs to the German Federal Employment Agency) for non-automatable tasks and categorize them as: analytical non-routine tasks, 
interactive non-routine tasks, this model when applied on Germany results in between 15 and 38\% of German employees at risk (Kropp \& Dengler, 2019). The last model was A-Task Based Approach by Melanie Arntz, Terry Gregory, 2016 in which they argue that FO Model Ignore that, the occupations consist of many tasks, part of them can be automated and another part cannot be. Also, FO assume that the occupations are the same everywhere, However the task structure is different from place to another. This model when applied on USA reduced the risk of automation from $47 \%$ to $9 \%$ only. They applied this models on OECD countries and the results was $9 \%$ (Arntz, Gregory, \& Zierahn, 2016). This model was applied on Northern Ireland indicates that $7 \%$ of Northern Ireland employees are at risk (Sórcha \& Lisa, 2019).

While working on this paper another important event in our life was happened, and it is expected to affect our way of living for many years which is COVID-19.

COVID-19 is a novel infectious disease caused by severe acute respiratory syndrome coronavirus 2 (SARS-CoV-2). The disease was first idented in 2019 in Wuhan, China, and has since spread globally, resulting in a pandemic. Most cases result in mild symptoms with an estimated death rate of about 3.4\%. The COVID-19 pandemic has had vast tragic human consequences. As of Mid-November 2020, there were over 55M confirmed cases and more than 1.3M fatalities worldwide. In addition, from being a human tragedy, COVID-19 is also an economic tragedy (Béland, Brodeur, \& Wright, 2020). By Mid November 2020, the total number of reported cases in Egypt was 111,613 and the reported death 6495 as shown in figure 1 (Coronavirus Cases, n.d.)

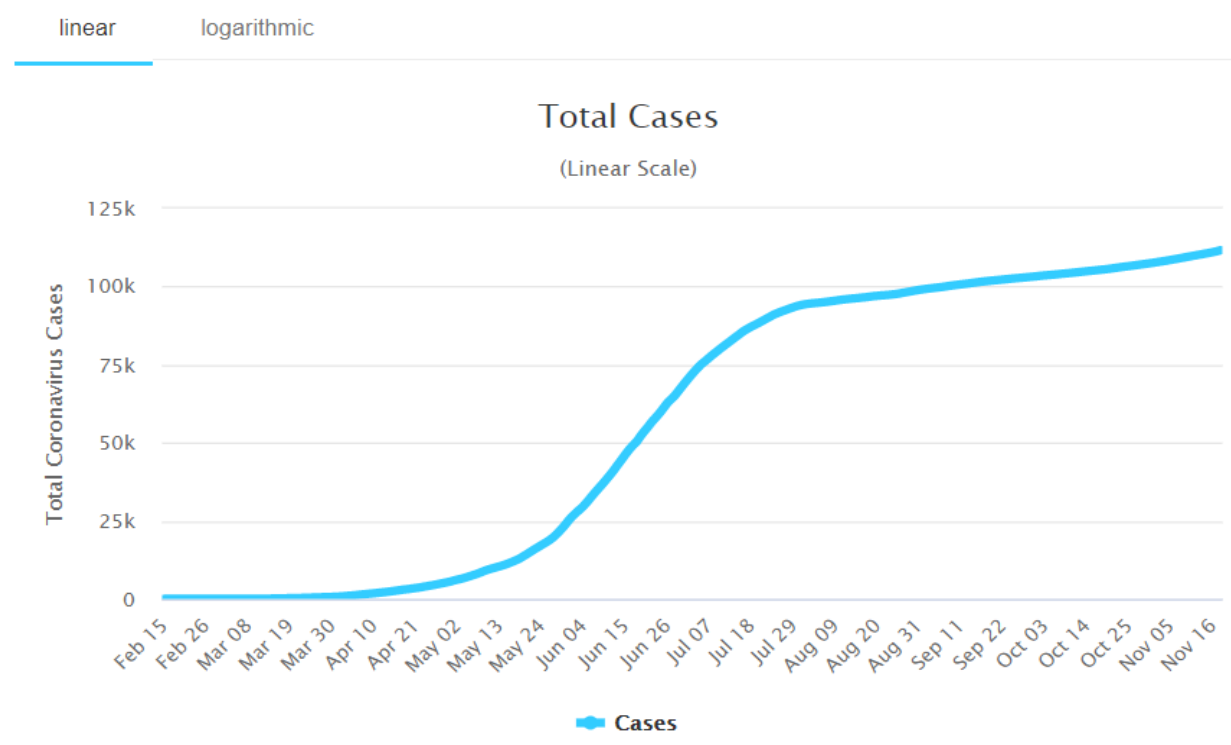

Figure 1. Coronavirus in Egypt

Source: https://www.worldometers.info/coronavirus/country/egypt/ (Coronavirus Cases, n.d.).

COVID-19 has an overall impact on unemployment and on specific occupation which demand high interaction with people, part of them was mandatory to continue, like health care workers and physician. Other jobs which was less important was forced to stop work. Additional demand happened in several countries for healthcare and. People with nature of office work which can be done from home through telecommuting devices was in safe zone against unemployment. In the other hand there was more demand on workers on delivery companies, Amazon Announce its need for 100,000 new job with increased pay $\$ 2$ per hour to meet the increased demand on online shopping (Béland, Brodeur, \& Wright, 2020). After COVID-19 containment the normal life will not become the same as before. Several lessons learned and habits weather its related to customers new behaviors or the way he was served. Which create the need to study the change in customers habits, behaviors and determine which of them will be continued after the pandemic (Alatovic, Chhaya, Juneja, Smaje, \& Sukharevsky, 2020).

The key objective of this thesis is to understand and quantify the impact of Automation\& Artificial intelligent technology on employment in the Mobile Operators in Egypt before and after COVID-19. We will apply The Task based Approach Model on the "Engineering-Bottlenecks" defined by Carl Benedikt Frey and Michael A. Osborne, and was operationalized in the ESJS operation models defined in the ESJS (European Skills and job survey) adding the assignment of activities which is defined by Alexandra Spitz-Oener, on one of the Mobile operators in Egypt as a sample from this Business Sector. 


\section{Problem Definition}

Several Tasks can be Suitable for Automation, and other Tasks is not suitable and become more valuable. New Machines will increase the productivity of the human being and will create efficiencies which will decrease the number of employees needed to perform the same tasks. During COVID-19, the behavior of the people and the organization was changed to allow more protection from the virus, such as using digital platforms in shopping, payment, and learning, WFH using the aid of digital platforms instead of going daily to the office. Such massive use of digital platforms and got the things done through them, happened in several months instead of several years, which was needed to create the digital awareness and convenience the people to use them, this will lead to an acceleration of the digital transformation and affect the employment in the near future.

Elsafty (2018) introduces a framework of nine elements to enable researchers to clearly formulate the problem definition, and a framework to analyze the case researched, especially within social studies. Elsafty provided a framework to analyze the case using 9 elements as shown in figure 2 (Elsafty, Sayad, \& Shaaban, 2020). covering the whole ecosystem of organization(s) and all related stakeholders; including suppliers, distributors, customers, competitors, government agencies, and so on whom involved in the delivery of the outcomes, and the related services.

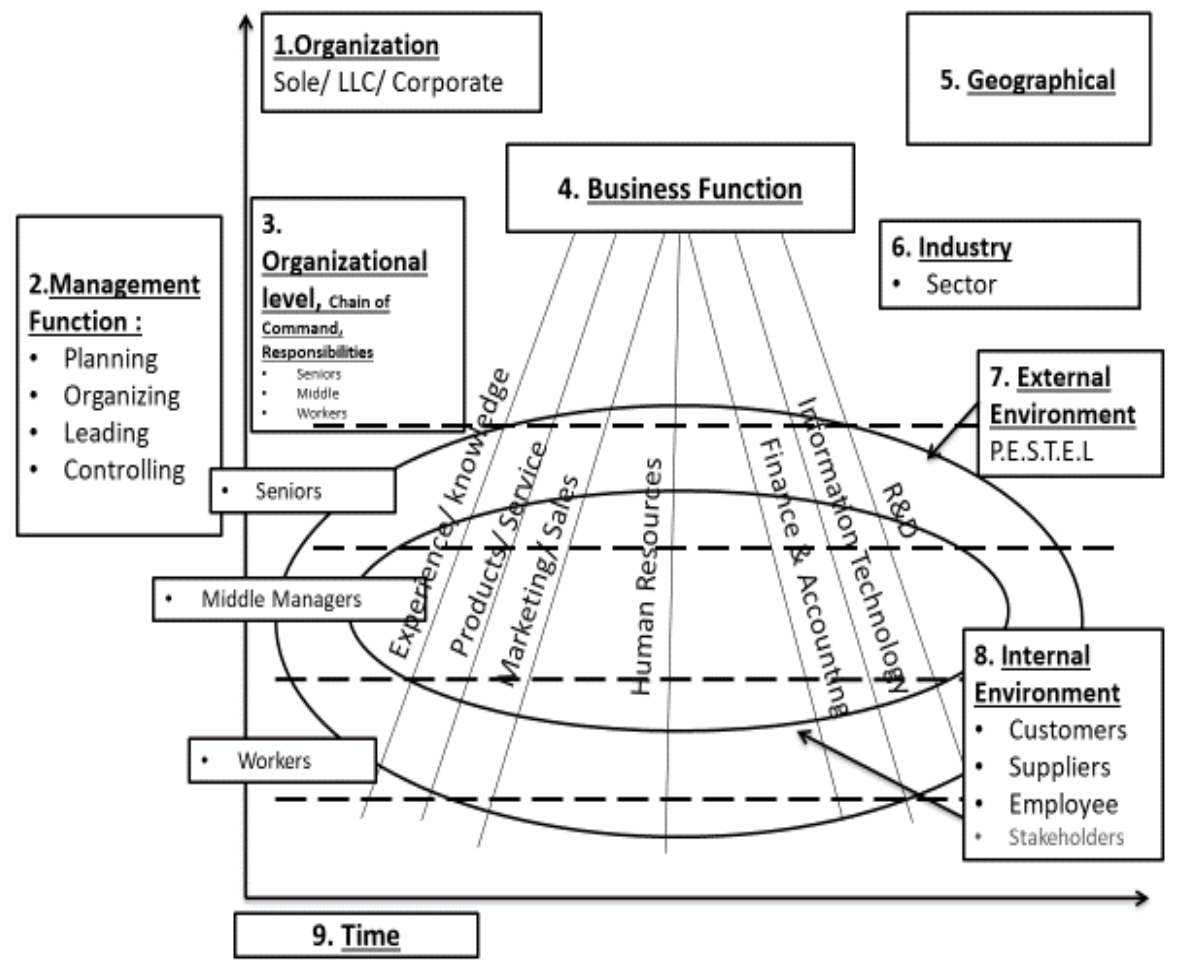

Figure 2. Business Anatomy Model/Framework Proposed by Elsafty (2018, 2-19, 2020)

Elsafty framework illustrate the interrelations among all elements affecting the research problem, where each element in the framework affects and being affected by the others, which create a constantly evolving relationships (Elsafty, Elsayed, \& Shaaban, 2020; Elsafty \& AlNawaly, 2020; Elsafty \& Ragheb, 2020; Elsafty \& Abadir \& Sharawy, 2020; Elsafty, A., Elbouseery, I., \& Shaarawy, A., 2020).

\section{1- Organization}

The Mobile Operators in Egypt consists of four Companies which are: Vodafone Egypt, Orange, Etisalat, and Telecom Egypt. We will study a sample from one organization, for data gathering possibility. The mobile operators are almost identical in their strategy towards Digitalization and will face the same challenge from COVID-19.

\section{2- Management Functions}

The management functions are planning, Organizing, Leading and Controlling.

\section{- Planning}

With digital transformation, Digitalization and Automation become on the top of the strategic objectives for all Mobile Operators. In which Higher management are taking a step back and revisiting everything they do, from internal systems to customer interactions to new digital products they can offer to the consumers. During COVID-19 planners should be 
clever to protect the company through reducing operating costs and expenditures, optimizing the capital investments through short term investment. Then can Be ready to invest for growth after the downturn (Mckinsey, 2019).

\section{- Organizing}

The Self-manage Agile Teams using Scrum Techniques became the new trend of how to organize the work which will eliminate the supervisors and reduce the middle management layers. One of the lessons learned during COVID-19 that Organizations which had not adopted or trained their employees on agile practices, starts to apply agile concepts to gain from its speed (Henke, Puri, \& Saleh, 2020).

\section{- Leading}

Digital capabilities became a mandate of hiring for higher management CEO, Exco HOD, Managers, supervisors. COVID-19 identify potential leaders who did manage the crisis and other potentials need upgrade through a training (Fitzpatrick, Gill, Ari Libarikian, Smaje, \& Zemmel, 2020).

\section{- Controlling}

Manage by objectives and quota for top performers is applied and the strategic objectives which digital transformation is on the top of the list are cascaded down to everyone. The experience from Controlling people during COVID-19 lockdown will be continued to manage the working from home expected pattern after that.

\section{3- Organizational level, Chain of Command, Responsibilities}

With Automation and digitalization there is a tendency towards de-qualification on the level of skilled workers or technicians, as these systems might lead to more automation in former domains dominated by human supervision, such as controlling, supervising, and scheduling activities. COVID-19 reveals that, the digital strategy of Major firm's will be led by CDO (Chief Digital officer) his role as depicted in figure 3 (Alatovic, Chhaya, Juneja, Smaje, \& Sukharevsky, 2020).

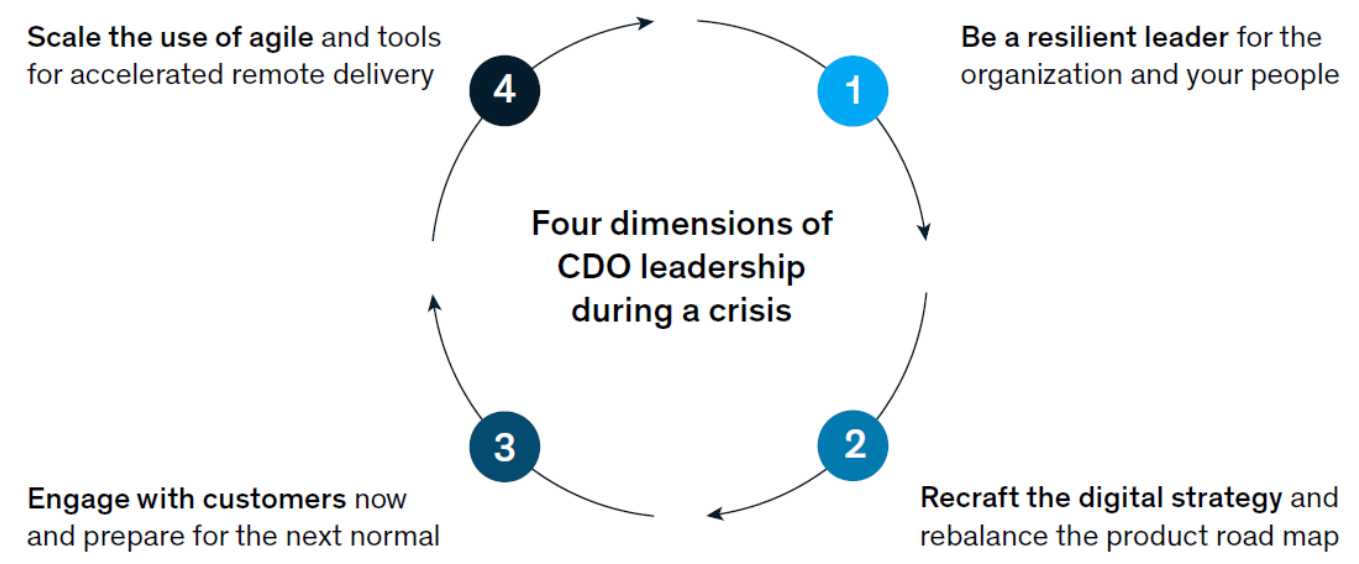

Figure 3. To lead their companies' digital response to the crisis, chief digital officers must act across four dimensions Source: Driving digital change during a crisis: The chief digital officer and COVID-19 (Alatovic, Chhaya, Juneja, Smaje, \& Sukharevsky, 2020)

\section{4- Business Functions}

The business functions are Experience/knowledge, Product/Service, Marketing/sales, Human Resources, Finance/Accounting, Information Technology and R\&D.

\section{- Experience/knowledge}

Previously all jobs were required bachelor's degree from university like Engineering in Technology, Business Administration in Marketing \& sales etc. The new era of Digital transformation will require new skills in which information technology will play a major role on the transformation. The top digital skills required for digital transformation will be:

a) Programming, Web and App Development.

b) Data Science and Data Analytics.

c) Digital Business Analysis.

d) Digital Design and Data Visualization. 
e) Digital Project Management with an understanding of SCRUM and AGILE.

f) Digital Product Management.

g) Digital Marketing.

h) Social Media PR.

These changes will require a New planning for the Future work force as some tasks will remain stable, new tasks will be created, and others will be obsolete. To decrease the negative effect on existing employment, Upskilling, and Reskilling for the current workforce are required to mitigate the effect of technological unemployment and to create new opportunities (Forum, 2018). COVID-19 and working from home will save transportation time which will increase the opportunity for training through online training which was not so preferred before the pandemic (Fitzpatrick, Gill, Ari Libarikian, Smaje, \& Zemmel, 2020).

\section{- Product/Service}

The Main products provided now is Voice, data services and recently added a Money Transfer services through mobile. In the future customers are expecting more and more to embrace digital as their primary means of doing business. New product and services could potentially create new jobs (Mckinsey, 2017). An indication from China, 55\% increase in consumers intending to permanently shift to online grocery shopping after the pandemic and increase of 3 to 6 points in overall E-commerce. We assume if people used to perform activities through a digital platform during the pandemic, they will continue use it which will save a lot for the producers and decrease the cost (Diebner, Silliman, Ungerman, \& Vancauwenberghe, 2020).

\section{- Marketing/sales}

With digital transformation the role will be different from its classic way, such as:

a. Digital marketing will open the door to marketing automation, analytics tracking, and dialogue with customers.

b. Social selling strategies will be a key component of digital transformations.

During COVID-19 stores were closed across the globe as well as in the telecom companies. Telecom companies as well as other industries start to depend on new sales ways in which it is depend mainly on self-service (Deloitte, 2020).

\section{- Human Resources}

In general, Human resources functions are Acquiring, Hiring, Training, and retaining. In the new era of digital transformation, the HR will play a major role in the training, targeting Upskilling and Reskilling. Also, it is expected that a new tasks will be created, and the ability of people previously engaged in other occupations to fulfil them depend on the Training. The biggest challenges to employment come from automation, in the form of robots and artificial intelligence. As we can see in figure 4 (Forum, The Future of Jobs Report, 2018), the Ratio between human to machine working hours in 2018 vs the projection of 2022. The machines will have a big share from the jobs.

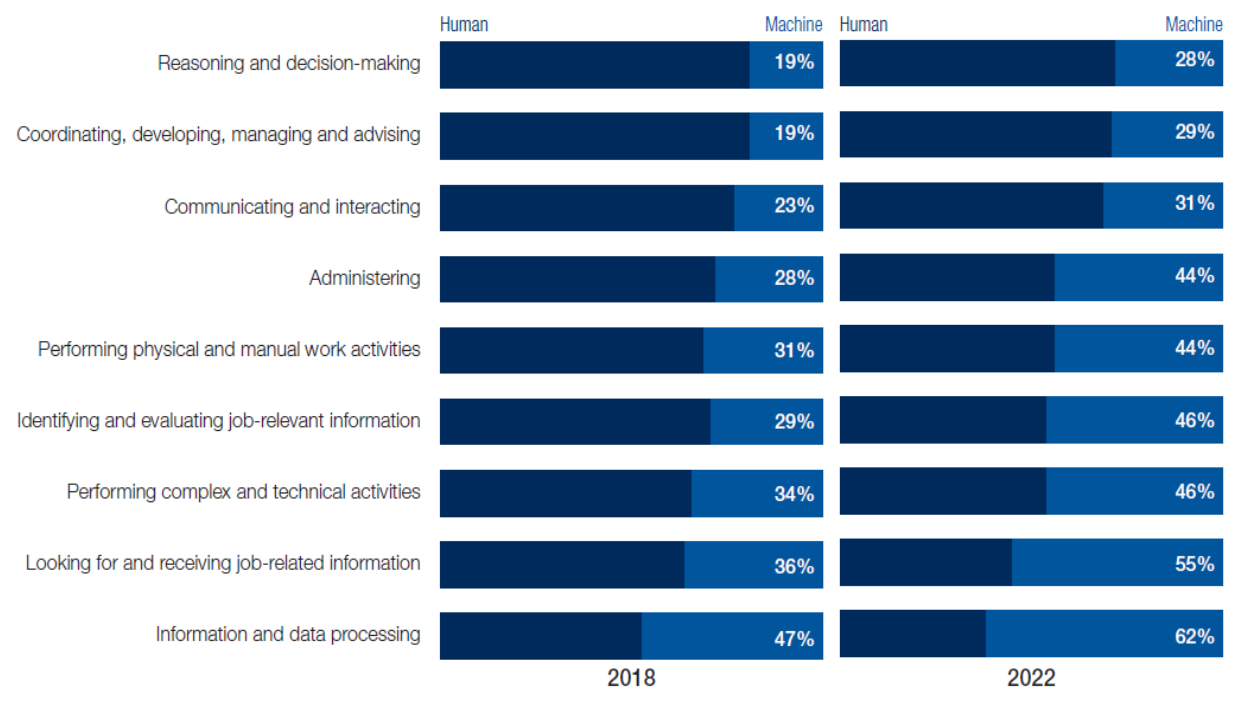

Figure 4. Ratio of human machine working hours 2018 vs 2022 (projected)

Source: The Future of Jobs Report, World Economic Forum, 2018 (Forum, The Future of Jobs Report, 2018).

Also, the projection of economist that digital transformation will create redundant jobs and will create new jobs and 
several jobs will remain Stable as shown table 1 (Forum, The Future of Jobs Report, 2018).

Table 1. Examples of stable, new, and redundant roles, all industries

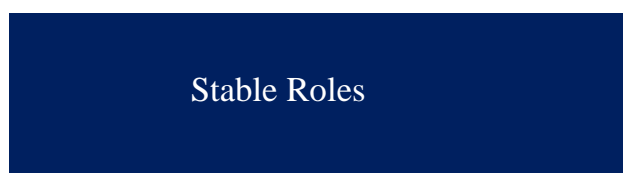

Managing Directors and Chief

Executives

General and Operations Managers

Software and Applications Developers and Analysts

Data Analysts and Scientists

Sales and Marketing Professionals

Sales Representatives, Wholesale and

Manufacturing, Technical and Scientific

Products

Human Resources Specialists

Financial and Investment Advisers

Database and Network Professionals

Supply Chain and Logistics Specialists

Risk Management Specialists

Information Security Analysts

Management and Organization Analysts

Electrotechnology Engineers

Organizational Development Specialists

Chemical Processing Plant Operators

University and Higher Education

Teachers

Compliance Officers

Energy and Petroleum Engineers

Robotics Specialists and Engineers

Petroleum and Natural Gas Refining

Plant

Operators

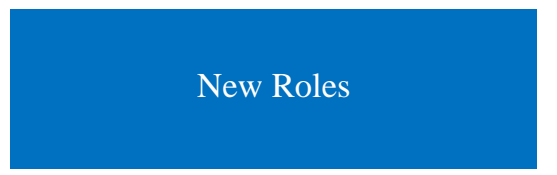

Data Analysts and Scientists

AI and Machine Learning

Specialists

General and Operations Managers

Big Data Specialists

Digital Transformation Specialists

Sales and Marketing Professionals

New Technology Specialists

Organizational Development

Specialists

Software and Applications

Developers and Analysts

Information Technology Services

Process Automation Specialists

Innovation Professionals

Information Security Analysts

Ecommerce and Social Media

Specialists

User Experience and

Human-Machine Interaction

Designers

Training and Development

Specialists

Robotics Specialists and Engineers

People and Culture Specialists

Client Information and Customer

Service Workers

Service and Solutions Designers

Digital Marketing and Strategy

Specialists
Redundant Roles

Data Entry Clerks

Accounting, Bookkeeping and Payroll Clerks

Administrative and Executive Secretaries

Assembly and Factory Workers

Client Information and

Customer Service Workers

Business Services and

Administration Managers

Accountants and Auditors

Material-Recording and

Stock-Keeping Clerks

General and Operations

Managers

Postal Service Clerks

Financial Analysts

Cashiers and Ticket Clerks

Mechanics and Machinery

Repairers

Telemarketers

Electronics and

Telecommunications Installers and Repairers

Bank Tellers and Related

Clerks

Car, Van, and Motorcycle

Drivers

Sales and Purchasing Agents and Brokers

Door-To-Door Sales Workers, News and Street Vendors, and Related Workers

Statistical, Finance and

Insurance Clerks

Lawyers

Source: The Future of Jobs Report, World Economic Forum, 2018 (Forum, The Future of Jobs Report, 2018).

During COVID-19 Working from Home (WFH) became the nature of work, which is expected to continue in the New

Normal, in most of the organizations. HR should start to put the rule for this type of work such as:

1- When do u work?

2- When to send emails and expecting reply (not at night or over the weekend)?

3- How to regain the energy? (McKinsey, 2020). 


\section{- $\quad$ Finance/Accounting}

More dependent on online payment and cashless environment. Finance will take the role of evaluating the costs of Humans vs Machines. During COVID-19 Telecom Sector was and will be impacted but it is doing well compared with other sectors in the S\&P 500 as per figure 5 (IFC, 2020), future growth is not guaranteed because of the effect on economy which will affect the customers working in may affected sectors. Revenues will be declined as the customers will decrease their expenditures (IFC, 2020).
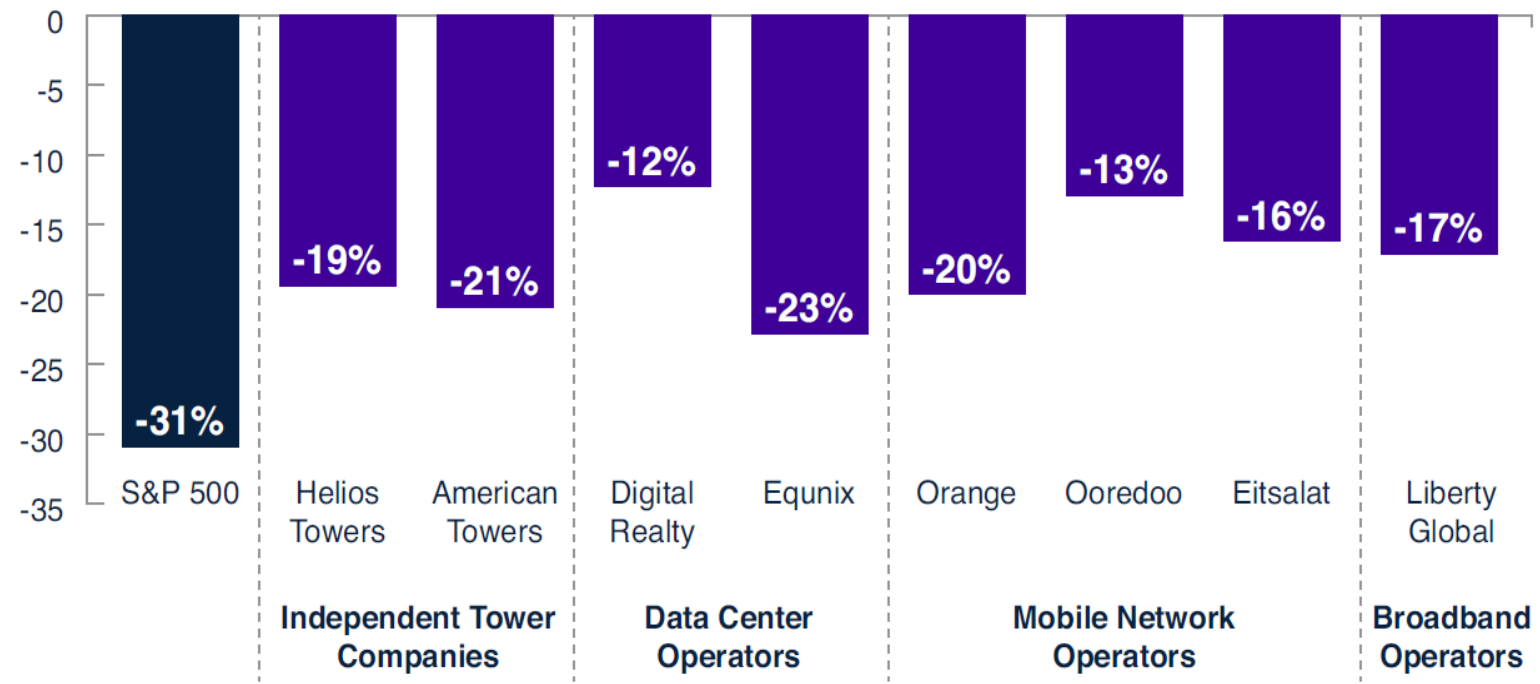

Figure 5. Performance of key global telecom players versus the S\&P 500 during the COVID-19 pandemic

Source: S\&P Capital IQ, based on the difference between the closing prices on February 21, 2020, when the stock market was first impacted by the pandemic, and March 20, 2020, when the stock market started to stabilize; all data retrieved from S\&P Capital IQ (IFC, 2020).

\section{- Information Technology}

Information technology is the heart of the digital transformation for all kind of business.

IT Also played and will play a major role during/after COVID-19 to enable the employee working from home as well as creating new digital channels for the customers "technology is a core driver of value, not merely a support function" (Fitzpatrick, Gill, Ari Libarikian, Smaje, \& Zemmel, 2020).

\section{- $\quad \mathbf{R} \& \mathbf{D}$}

Mobile Operators are investing to build and acquire experts in AI and Machine learning and developing Agile teams on their focus on Automation and developing digital products and services. We can notice that during COVID-19 as "necessity being the mother of invention", Engineers in china built 2 hospitals from scratch in 1 week only. one European retailer launches new e-commerce in 13 weeks (Fitzpatrick, Gill, Ari Libarikian, Smaje, \& Zemmel, 2020). $\mathrm{R} \& \mathrm{D}$ will shape the future for all organizations in this changing time.

\section{5- Geographical}

Digital Transformation and COVID-19 penetrate the whole world which will affect all countries around the world. Compared to the other world Egypt will have a limited impact from the Digital transformation as shown in figure 6 (Mckinsey, 2017). However Mobile operators are following the trend of the European Operators (Mckinsey, 2017). Similarly, COVID-19 is impacting the whole world with also a different intensity as shown in figure 7. 


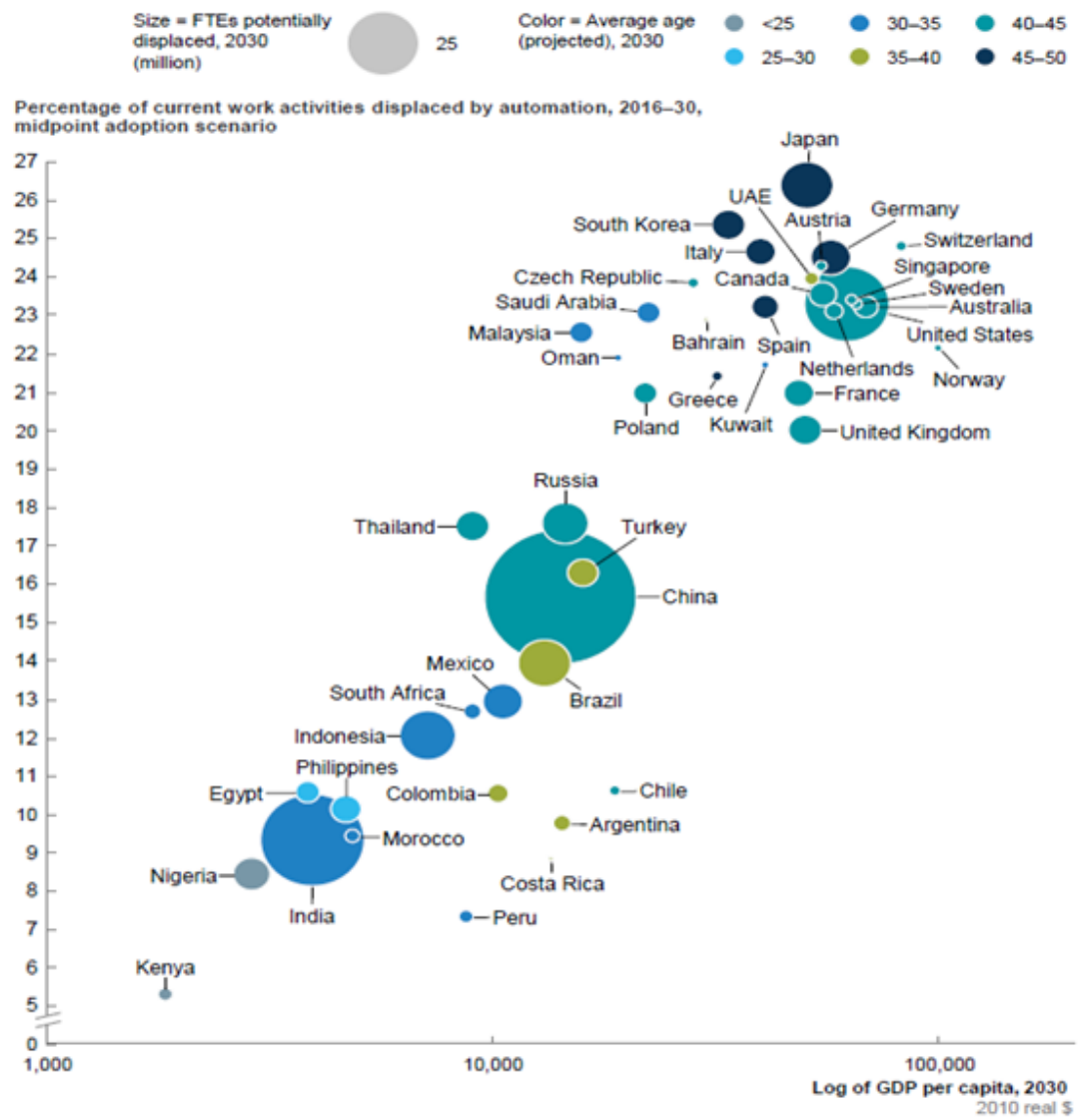

Figure 6. Impact of automation varies by a country's income level, demographics, and industry structure

Source: jobs lost, jobs gained: workforce transitions in a time of automation, Mckinsey Global Institute, 2017 (Mckinsey, 2017).

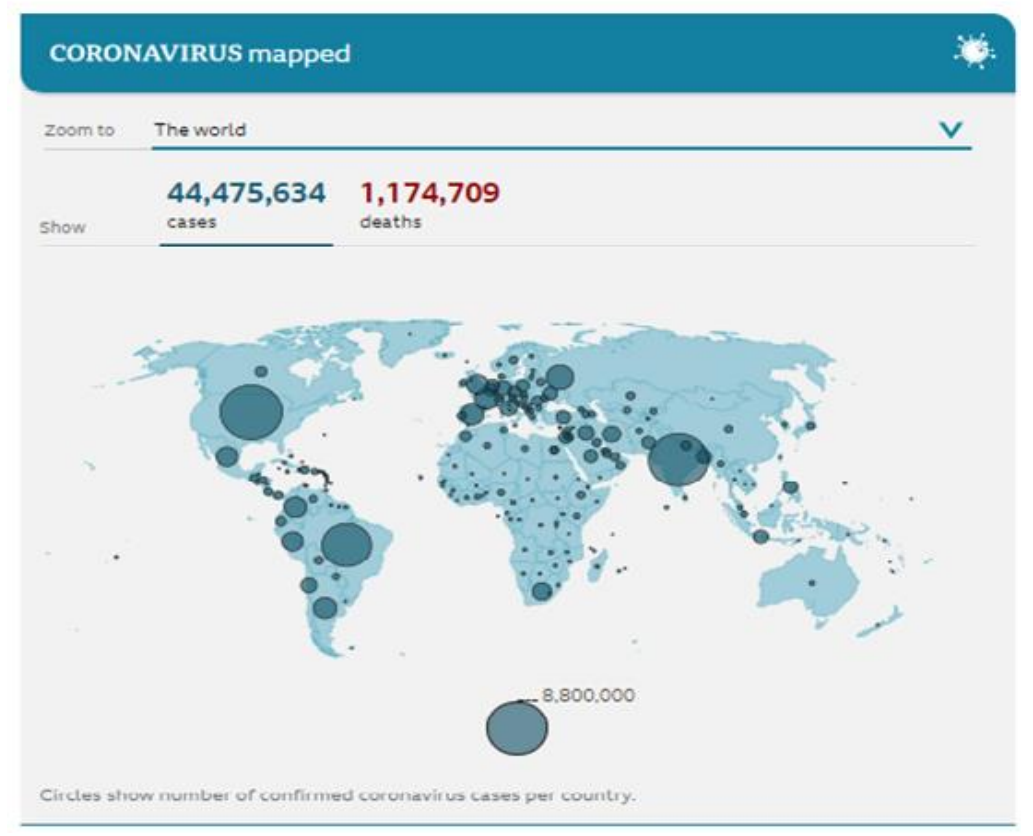

Figure 7. COVID-19 Map

Source: Johns Hopkins University, national public health agencies.

Figures last updated 29 October 2020, 11:08 GMT 


\section{6- Industry}

Although most Industries will be affected the research will focus on telecommunication and Egypt mobile operators for the possibility of access and gathering information. Similarly, COVID-19 will affect the whole world which depend on mobile and fixed Networks, as a prime mean for communication, and entertainment (Deloitte, 2020).

\section{7- External Environnement (P.E.S.T.E.L)}

\section{- Political}

In 2030 Egypt vision Towards the digital transformation was stated in 3 objectives:

32. Transform Egypt to a global digital hub.

33. National project for high-speed internet.

34. Developing the digital community to enhance efficiency and transparency for all institutions (Egypt Vision 2030, 2016).

During COVID-19, E-Governmental was spread like E-shopping, which allowed a lot of people to receive governmental services via digital means, this could impact the governmental employees when things return to the New Normal after the pandemic.

\section{- Economic}

Real GDP growth in Egypt reached 5.6\% in FY19, up from 5.3\% in FY18. Unemployment decreased to 7.5\% in Q4-FY19 (from 9.9\% a year earlier), economic growth is expected to reach 6\% by FY21 (WorldBank, 2019).

A Rapid growth in computation and artificial intelligence is expected which will cause economic growth with accelerated pace. However, this expectation is tested by William D. Nordhaus not to be in a near future (Nordhaus, 2015). Economic flourish will affect the employment positively However The unemployment rate might severely impacted due to high rate of growth of digital transformation. Recent research indicates that by 2030 between almost zero and 30 percent of the hours worked globally could be automated (Mckinsey, 2017).

There are 3 scenarios for COVID-19:

1 - regional recurrences of the virus, a muted recovery, and slower longer-term growth.

2- virus containment, sector damage, and a lower growth rate over the long term.

3 - the virus recurs and economic-policy interventions cannot deliver a full recovery to precrisis levels.

Scenario2 is the most chosen scenario by executives and economists to occur (Mckinsey, Economic Conditions Snapshot, September 2020: McKinsey Global Survey results, 2020).

\section{- Social}

As stated by Voltaire "Work saves a man from three great evils: boredom, vice and needs". works not only provide people with money but also provide us with self-worth, community, engagement, healthy values, structure, and dignity. Work is beneficial to people and community (Brynjolfsson \& Andrew, 2014). In a short period of time, COVID-19 affect our lives and livelihoods around the globe even the habits and behaviors were changed, what was consider simple like going to a grocery or visiting friends became difficult now and sometime prohibited. Satisfying demand channels now became different. People will need digital channels with a few touches to fulfil their needs. Digital will continue to grow and companies who will establish a good repetition in the pandemic time will have a good repetition afterwards (Diebner, Silliman, Ungerman, \& Vancauwenberghe, 2020).

\section{- Technological}

Digital transformation will depend mainly on new technology such as:

a. Smart Phones.

b. Cloud Enabled.

c. Omni Channel Experience.

d. Full Contact Centre Functionality.

e. Integrated Machine Learning and Artificial Intelligence.

F. f. Cyber Security, etc.

Figure 8 (Forum, The Future of Jobs Report, 2018). Shows that, by 2022 Companies are projected to adopt a new technologies which in turn will require different skills. 


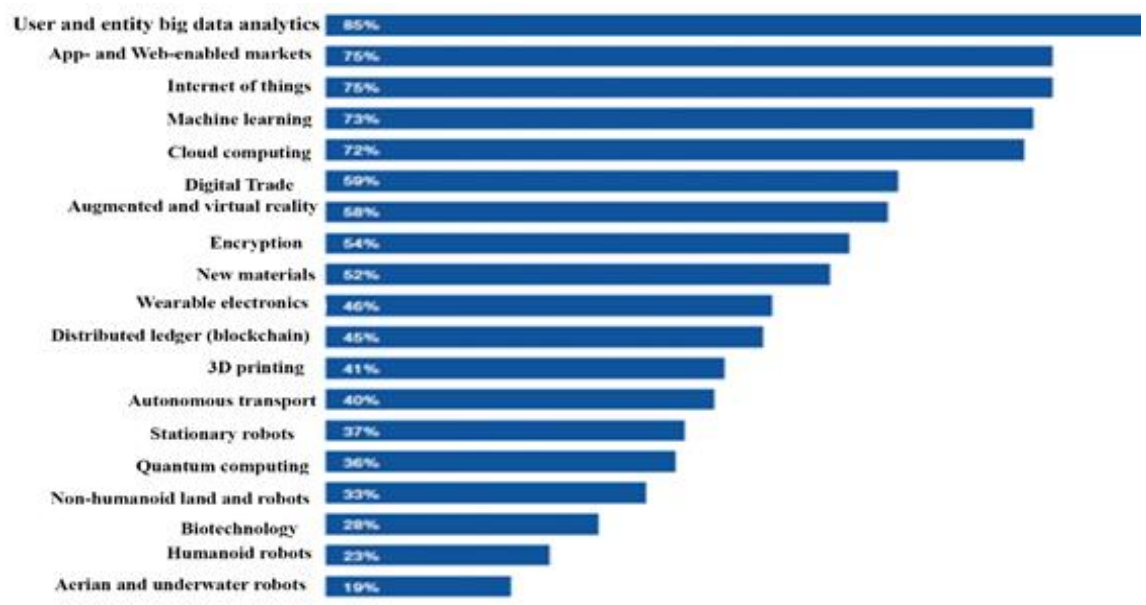

Figure 8 . Technologies by proportion of companies likely to adopt them by 2022 projected

Source: The Future of Jobs Report. World Economic Forum, 2018 (Forum, The Future of Jobs Report, 2018).

COVID-19 increased the need of videoconferencing and other collaboration tools, Digital Applications for shopping and E-payment. This will require a Network modification to adopt to the increase in the upload in which it was designed to accommodate only the downloads (McKinsey, 2020). Also, the increase use of E-payment and E-shopping will require a great focus on Cyber security.

\section{- Environmental}

Egypt suffers from weak infrastructure to enable Digital transformation, there is a need of high-speed internet, which is not possible now due to a limitation in Bandwidth and fiber optics cables which is monopolized by Telecom Egypt. Also, high value was placed on spectrum for $4 \mathrm{G}$ which will preclude the introduction of the 5G. Although the disasters caused by COVID-19, The one who only benefits are the surrounding environment. The lockdown and the movement restrictions as well as the decrease in the industrial activities helped in reducing the $\mathrm{CO} 2$ Emission and the destruction of the forests and other natural resources (Lokhandwala \& Gautam, 2020). It is expected that more attention will be taken worldwide on Health-related issues which proven by the spread of COVID-19 from china to the rest of the world that the world is a small country.

\section{- Legal}

The employment in Egypt in the private sector is according to law n ${ }^{\circ} 12$ of 2003 one of the articles of this low is "the contract of employment shall terminate at the expiry of a fixed-term contract or at the completion of the task for which the contract was concluded" (Trannet, n.d.). Which made all the employers made a one-year contract for its employee and renew it or not by the end of the year. This made them easily can get rid of any excessive workers by the end of his yearly contract without financial compensation even if he was working for 10 years. Also, Egypt does not have unemployment insurance. These two factors cause a loss of job is very painful to the employees in Egypt and easier to the employer.

\section{8- Internal Environment}

\section{- Customers}

Digital transformation begins and ends with the customer. The customers are almost everyone above 12 years in the country. Digital transformation will add a value to every customer interaction. Customers will require digital products, and if their current supplier cannot provide them with their requirement they will search for another provider.

During COVID-19 people around the country were confined to their home and was forced to use the internet application such as zoom and skype for working, learning and other applications for shopping and payments (McKinsey, 2020). The expectation that such new habits will be continued.

\section{- $\quad$ Suppliers}

Traditional Suppliers will have a fierce competition from small \& Medium size Suppliers. Mobile Operators will look forward on producing its needs mainly from SW products for exclusivity. This will push the cost down and will increase the employment in the Mobile Operators at the expense of the employment in the suppliers.

During COVID-19 all suppliers will be affected by supply chain of materials because of closed factories and delayed transportation, which may continue for long time after COVID-19 because of precautions actions (IFC, 2020). 


\section{- Employee}

Digital transformation will change employment. The biggest challenges to employment will be from automation, in the form of robots and artificial intelligence. Several jobs will be obsolete, others will be reduced, and new jobs will be created.

Ericsson (A Major telecom supplier) did a survey for its employees and the majority state "We're as productive or even more productive" at home (McKinsey, 2020). Of course such produtivity at home can be an opporunities for the companies to cut the employment for the sake of creating more efficiency.

\section{- $\quad$ Stake holders}

All stakeholders will be affected as the Game will Change and COVID-19 changes are touching everything.

\section{9- Time}

Although The effect of digital transformation on employment will increase in a hyper manner year over year. We are interested in the transition period from the start of automation till we reach a full automation.

No expected time for COVID-19 to be contained but what we sure about that there will be a learning and best practice on how we work during the pandemic in which will continue after the containment and might affect the employment.

\section{Literature Review}

The steam engine, the age of science \& mass production and the rise of digital technology are the first three industrial revolutions which made a huge transformation on the whole world. And it is happening again for the fourth time as we are witness right now the beginning of the Fourth industrial revolution which is powered by Artificial Intelligence, Cloud Computing, social Media, Mobile and the internet of things (IOT) along with increasing computing power and data, which will shape how we work, produce, consume, and live.

\subsection{The Fourth Industrial Revolution}

Each of the previous industrial revolutions represents major change, life went from farming to manufacturing, people moved from town to cities. How people lived and worked create the needs for electricity and mass production. Recently the digital revolution entered every industry transforming again how the people, work, live and communicate. The fourth industrial revolution amplify what is invented in the third one. Computer became a super-computer allow more usage of artificial intelligence which need processing more images and logics in shorter times. Creating unexpected innovations in Robotics using advances sensors which collect and process huge amount of data, store it in clouds instead of the traditional storage medias. These robots can perform a lot of tasks with little human-being intervention. Machines can interacts using high speed internet which would pave the way for the internet of things (IOT) which enables Machines to communicate with each other on a real-time basis allows a new applications such as remote surgeries (Bonekamp \& Sure, 2015). New technologies will serve the existing needs by better quality and prices in which will disrupt the existing industries and its related value chains. The difference between the $4^{\text {th }}$ revolution and the previous one is that it follows an exponential growth graph rather than a linear one. The spread almost in all countries and industries which will change the consumer behavior to use a welfare products such as remotely ordering a cab, booking a flight, buying a product, making a payment, listening to the music, watching a film, or playing a game. Brynjolfsson and Andrew McAfee mentioned that when return on capital will be higher than the return on human-being, the labor market will be disrupted and it will be most likely a combination of low-skills/low pay and high-skill/high-pay segments This risk of inequality is a major concerns of the $4^{\text {th }}$ revolution although a new jobs can be created (Schwab, 2016). The innovators will be in the top of the survivors as talented people will represent the major force of production in the digital world (Min Xu, David, \& Kim, 2018). Loss of jobs will impact tax revenue, public pension funds, VAT, Healthcare system and employment of young people. All of this will be on risk (Prisecaru, 2016).

On the contrary, Boston Consulting Group, in a study for a German management journal give a positive scenario in which Industry 4.0 will create 100,000 new jobs in next 10 years. Their argument was based on, new technology implementation will need a significant amount of technical expertise (Bonekamp \& Sure, 2015). One of the main fields that employment will flourish during the $4^{\text {th }}$ revolution age is the ICT field in which Cedefop forecasts another half a million new jobs in ICT occupations by 2025 (Cedfop (European Center for the Development of Vocational Training), 2017).

Is this revolution same like the previous ones? Is there an effect on inequality which was increased in the last 30 years? Which jobs will be affected, and which new skills are needed? How the nature of work like value and security will change? (Doménech, García, Montañez, \& Neut, 2017). It is important to study the $4^{\text {th }}$ revolution effect on all industries to be ready for remedy this problem before it become uncontrollable and We should put people first and empowering them and avoid robotize humanity which deprive our heart and soul (Schwab, 2016). 


\subsection{Unemployment}

Unemployment is when a person who is seeking a work to fulfill his needs is unable to find a work. Unemployment is a measure of a healthy economy. The most frequent measure of unemployment is the unemployment rate, which is the number of unemployed people divided by the number of people in the labor force. One of the goals of the governments is to reduce the unemployment through an economic development programs via increase capital investments through the public sector and pave the way to the private sector to invest and boosting the demand which create welfare and creating jobs (Dhaka, 1998). The most important factors in measuring unemployment are how many are affected for how long, and the ability of the new entrants to the labor market to find jobs (Autor, 2015). As shown in Figure 9 unemployment has a several types.

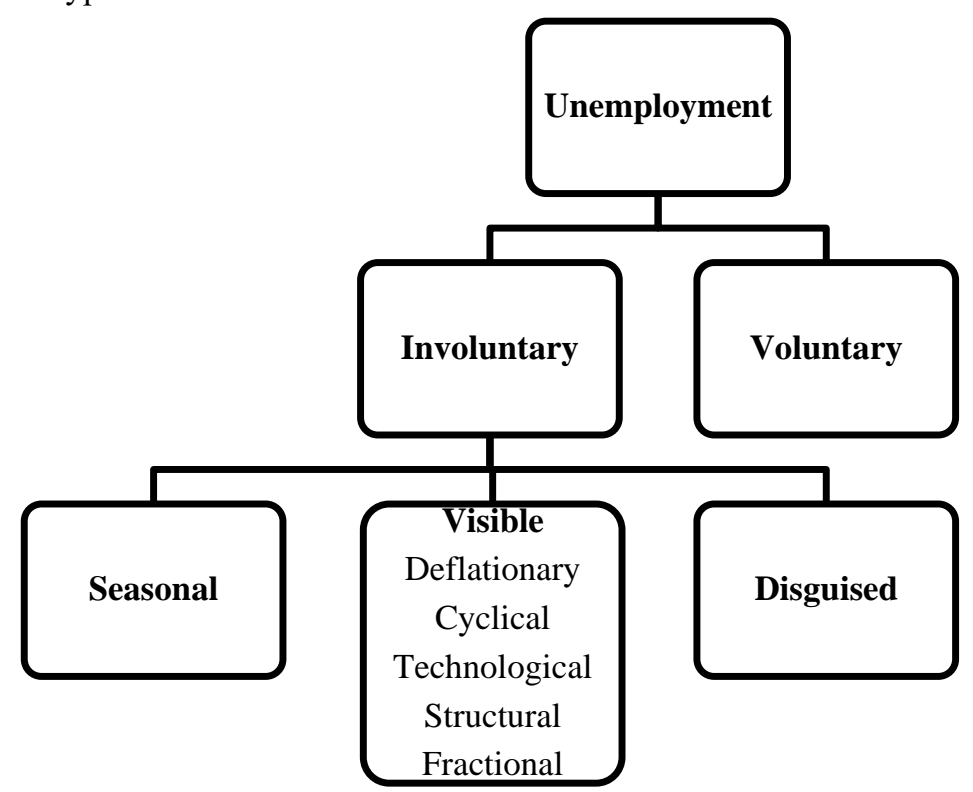

Figure 9. Unemployment types

\section{Voluntary Unemployment}

Those persons who are willing to work at current wage rate they might be idle rich, or they already worked and made fortune.

\section{Involuntary Unemployment}

Unemployment due to insufficient jobs for weeks, months or few years. It took several forms disguised, visible and seasonal.

\section{- Disguised Unemployment}

It is the part of the labour force which can be released without affecting the productivity of the society.

\section{- Seasonal Unemployment}

The lack of productive work during some periods of year because of climate change which affect the touristic areas or in the agriculture the time between post-harvest and next snowing.

\section{- Visible Unemployment}

The lack of jobs for certain numbers of workers for some periods. This includes the laid off workers and the new entrants to the labour market. Visible Unemployment take the following forms:

\section{a) Deflationary Unemployment}

Higher saving ratio and other factors create less cashflow and decrease the consumption, which in turn decrease the demand on products and services and its related employment.

\section{b) Cyclical Unemployment}

The economic cycles as well as the business cycle of the firm Introduction, growth, maturity, and decline.

\section{c) Technological Unemployment}

Results from the failure of the labour force to adjust to the technical changes which occurs because of the introduction of new machine and systems (Dhaka, 1998). 


\section{d) Structural Unemployment}

unemployment that results because the number of jobs available in some labor markets is insufficient to provide a job for everyone who wants one.

\section{e) Frictional Unemployment}

unemployment that results because it takes time for workers to search for the jobs that best suits their tastes and skills (Mankiw, 2003).

\subsubsection{Consequences of Unemployment}

Losing a job is harming people life, they lose their earning source, sense of achievement, reduce their self-esteem and create anxiety about the future which sometimes cause psychological illness (Mankiw, 2003).

Unemployment has the following consequences:

1) It precludes the attainment of economic and social development as well as decrease the demand on workers which in turn reduce the wages.

2) It ruins the dignity and self-respect.

3) creates frustration and tension.

4) Increase the violence for regaining status and sense of purpose.

5) It increases the internal competition to unhealthy limits.

6) It can increase the children working to compensate the lost income of the parents.

7) Can lead to society unrest.

8) Can lead to suicide to avoid pains and commitments.

9) Can lead to mental disruption.

10) Furnishes both the opportunity and the motive for crime.

11) Less collected taxes (Dhaka, 1998).

As stated by Voltaire "Work saves a man from three great evils: boredom, vice and need". Works not only provide people withs source of living but also provide them with a purpose of existence which benefit them and the society. Employment not just a contractual relationship, it reduces crimes, strengthens the community in which should be rewarded not taxing it. The freed-up time and energy for the unemployed is a challenge facing policy makers (Brynjolfsson \& Andrew, 2014).

A significant portion of unemployed due to technology change will be older adults with low education level, having train them to be re-engaged in the work force will be extremely hard. This will have huge social impact in which the development of the right policies can mitigate these effects (Fuei, 2017).

As COVID-19 began to spread by March 2020, school closed, workers sent home and most of the essential services was closed. More than 31 Million applications for unemployment insurance were filled during March and April in USA. The unemployment rate in USA reached $14.7 \%$ and a lot of people was laid off. The new entrants and re-entered work force were almost put-on hold. The labor participation rate reaches $60.2 \%$ in USA which is the lowest rate measured since 1970s. Most companies started to implement working from home policies and business owners and managers started to assess the new normal after the pandemic. Permanent job loss is occurring slowly, with each day bringing new numbers. The future is susceptible according to the duration will be taken in this pandemic affecting the newly created business to absorb the new entrants and the re-entering of the work force which increase the probability for long term unemployment (Stevenson, 2020).

\subsection{Automation and AI}

Automation started with the routine tasks, which was converted to a systematic code in a computer program. However, over the last decades we can observe that machine started with mechanical than electromechanical and Digital. The same with computers started as a systematic sequences and logic turning to be able via AI to compare millions of image patterns and millions of data and take a decision and learn (Brynjolfsson \& Andrew, 2014). In the near future computer through AI can substitute more complex tasks such as legal writing and truck driving, however several tasks which mainly depends on human communication skills will be difficult to automate such as jobs depends on communication skills, like persuading and negotiation skills (Frey \& Osborne, 2013). "what can be automated, will sooner or later be automated, making human work redundant" (Csefalvay, 2019). Several prediction Models was developed and applied in many countries to estimate the effect of the automation on unemployment. 
The Task Model: This model produced by David H. Autor, Frank Levy, and Richard J. Murnane. The target of this study was to study the relation between computer and computer usage. They argue that computer can do the following:

1. Substitutes workers performing routine tasks by following programmed sequence and rules.

2. complements workers performing nonroutine and complex tasks (Autor, Levy, \& Murnane, 2003).

An Occupation-Based Approach: This model was produced by Carl Benedikt Frey and Michael A. Osborne. The model was developed using o*net, an online service developed for the us Department of Labor. FO infer that $47 \%$ of all jobs in the US are in the high-risk category in which the Following Tasks cannot be automated now as illustrated in Figure 10 (Frey \& Osborne, 2013).

1- Perception and Manipulation tasks: Robots are still unable to match the depth and breads of human perception.

2- Creative intelligence tasks: The psychological processes underlying human creativity are difficult to specify.

3- Social intelligence tasks: Human social intelligence is important in a wide range of work tasks such as those involving negotiation, persuasion, and care (Frey \& Osborne, 2013).

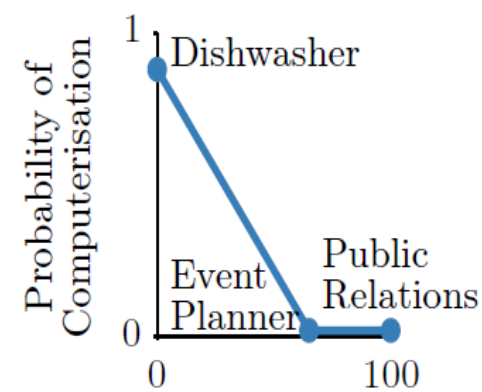

Social Intelligence

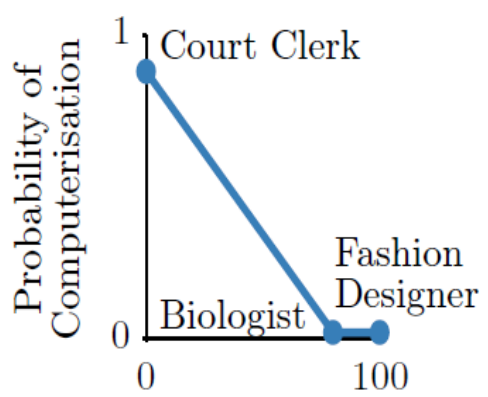

Creativity

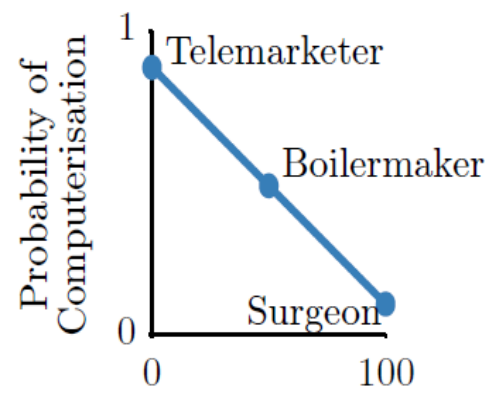

Perception and manipulation

Figure 10. A sketch of how the probability of computerization might vary as a function of bottleneck variables Source: The Future of Employment (Frey \& Osborne, 2013).

FO than made 3 categories low risk jobs (less than 30\%), medium risk (30-70\%) and high-risk ( $>70 \%)$ occupations. Applying this on the bureau of labor statistics the result was $47 \%$ of US jobs in high-risk zone, As illustrated in Figure 11 (Arntz, Gregory, \& Zierahn, 2016).

Manufacturing jobs will be subjects to automation except the jobs which in bottlenecks. The low-skilled jobs will be computerized in the near future in contrast to the high skilled which will not in the near future (Frey \& Osborne, 2013).

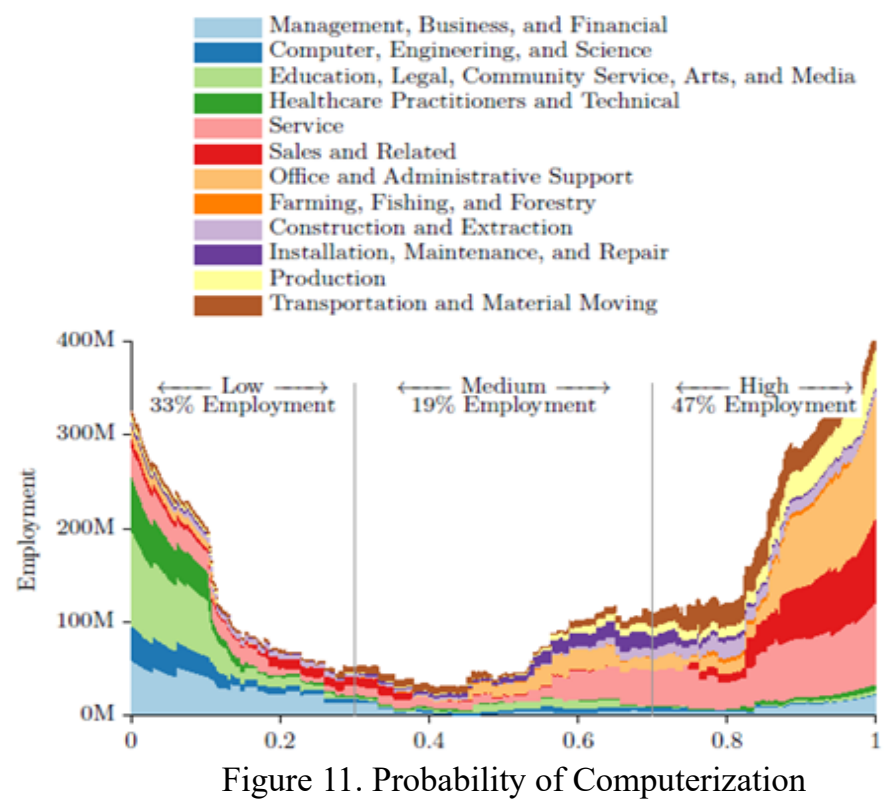

Source: The Future of Employment (Frey \& Osborne, 2013). 
Automation Risk in EU Market: This study was Made by Konstantinos Pouliakas who adopts Frey and Osborne model to identify the risk of automation across a sample of EU employees. In this model they use data from the European Skills and Jobs Survey (ESJS) which collect an information about the skills needed in the job. The output of this model revealed that $14 \%$ of EU employees their jobs are subject to automation especially whom working in routine jobs (Pouliakas, 2018).

Table 2 illustrates the correspondence between ESJS-related variables and Frey\& Osborne engineering bottlenecks (Pouliakas, 2018).

Table 2. ESJS variables corresponding to Frey and Osborne identified engineering bottlenecks

\begin{tabular}{|c|c|c|c|c|}
\hline $\begin{array}{l}\text { Computerization } \\
\text { bottleneck }\end{array}$ & O*net Variable & O*net Description & ESJS variable & ESJS definition \\
\hline \multirow[t]{3}{*}{$\begin{array}{l}\text { Perception } \\
\text { and } \\
\text { Manipulation }\end{array}$} & $\begin{array}{l}\text { Finger } \\
\text { Dexterity }\end{array}$ & $\begin{array}{l}\text { The ability to make precisely } \\
\text { coordinated movements of the } \\
\text { fingers of one or both hands } \\
\text { to grasp, manipulate, or } \\
\text { assemble small objects. }\end{array}$ & \multirow[t]{2}{*}{ Technical skills } & \multirow{2}{*}{$\begin{array}{l}\text { Specialist knowledge } \\
\text { needed to perform job } \\
\text { duties; Knowledge of } \\
\text { particular products or } \\
\text { services; Ability of } \\
\text { operating specialized } \\
\text { technical equipment }\end{array}$} \\
\hline & $\begin{array}{l}\text { Manual } \\
\text { Dexterity }\end{array}$ & $\begin{array}{l}\text { The ability to quickly move } \\
\text { your hand, your hand together } \\
\text { with your arm, or your two } \\
\text { hands to grasp, manipulate, or } \\
\text { assemble objects. }\end{array}$ & & \\
\hline & $\begin{array}{l}\text { Cramped } \\
\text { Workspace, } \\
\text { Awkward } \\
\text { Positions }\end{array}$ & $\begin{array}{l}\text { How often does this job } \\
\text { require working in cramped } \\
\text { workspaces that requires } \\
\text { getting into awkward } \\
\text { positions? }\end{array}$ & NA & \\
\hline \multirow[t]{3}{*}{$\begin{array}{l}\text { Creative } \\
\text { Intelligence }\end{array}$} & \multirow[t]{3}{*}{ Originality } & \multirow[t]{3}{*}{$\begin{array}{l}\text { The ability to come up with } \\
\text { unusual or clever ideas about } \\
\text { a given topic or situation, or } \\
\text { to develop creative ways to } \\
\text { solve a problem. }\end{array}$} & $\begin{array}{l}\text { Problem } \\
\text { solving skills }\end{array}$ & $\begin{array}{l}\text { Thinking of solutions } \\
\text { to problems; Spotting } \\
\text { and working out the } \\
\text { cause of problems }\end{array}$ \\
\hline & & & Learning skills & $\begin{array}{l}\text { Learning and applying } \\
\text { new methods and } \\
\text { techniques in your job; } \\
\text { adapting to new } \\
\text { technology, } \\
\text { equipment, or } \\
\text { materials; Engaging in } \\
\text { own learning }\end{array}$ \\
\hline & & & Learning tasks & $\begin{array}{l}\text { How often, if at all, } \\
\text { does your job involve } \\
\text { 'learning new things'? }\end{array}$ \\
\hline
\end{tabular}




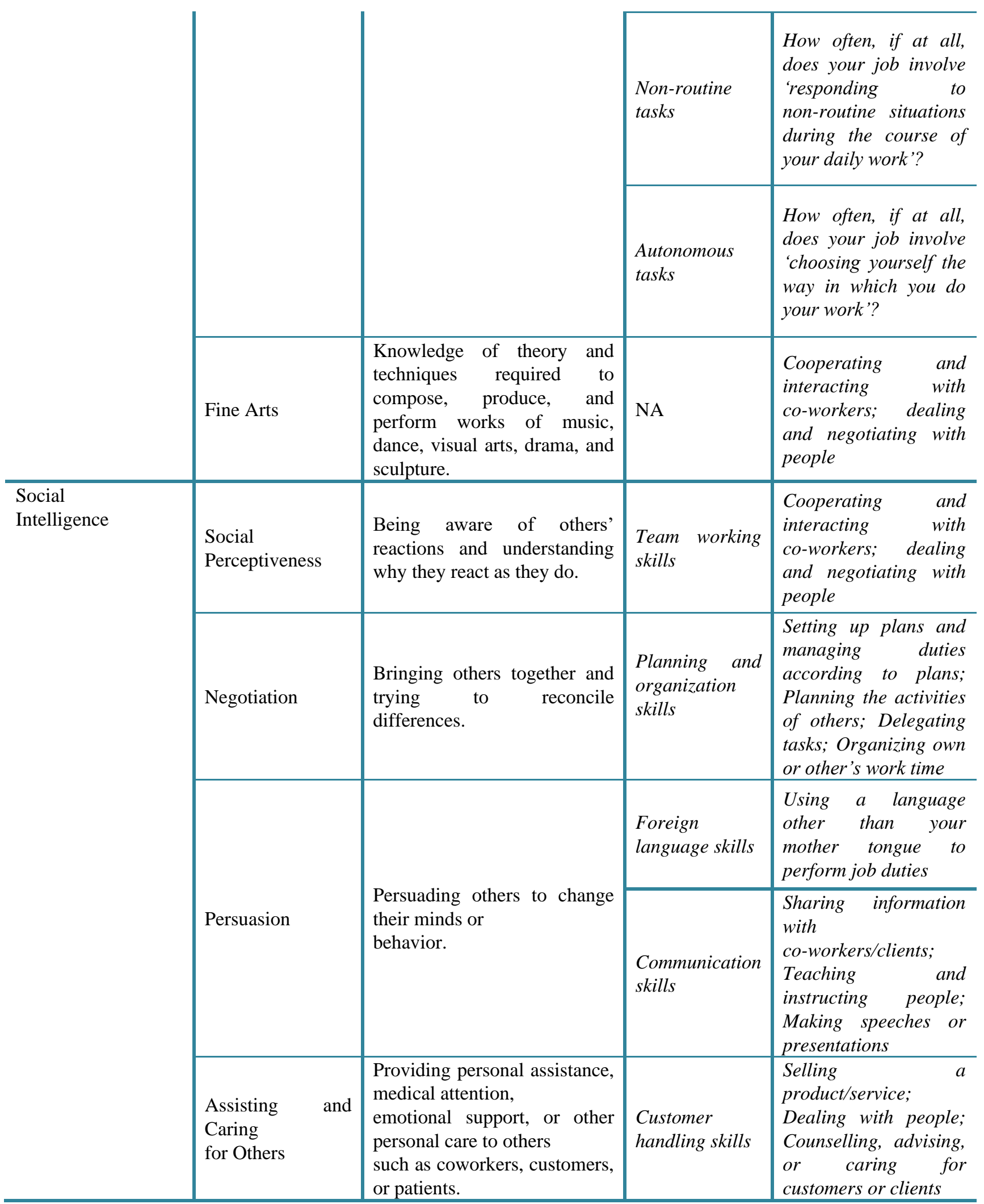

Source: Determinants of Automation Risk in the EU Labour Market: A Skills-Needs Approach (Pouliakas, 2018).

Automation Risk in Spain: This study was Made by R. Doménech, J. R. García, M. Montañez and A. Neut Applied whom adopts Frey and Osborne Model on Spain Employment using the microdata from 2011-2016 annual Labour Force Survey (EPA), The results show that on aggregate 36\% of current jobs are at high risk of automation (Doménech, García, Montañez, \& Neut, 2017). 
Automation Risk in Finland: A Study made by Mika Pajarinen and Petri Rouvinen indicate that One third of Finnish employment is highly susceptible to computerization using Frey and Osborne methodology and the data of Statistics Finland's (Pajarinen \& Rouvinen, 2014).

Automation Risk in Singapore: A study made by Lee, King Fuei, indicates that One-quarter of Singaporean employment is at high risk of computerization using Frey and Osborne methodology and Singapore employment counts 2014 (Fuei, 2017).

Occupational Tasks in the German Labour Market: Katharina Dengler, Britta Matthes and Wiebke Paulus use the assignment of activities explained by Alexandra Spitz-Oener in which they are applying it on BERUFENET Database (belongs to the German Federal Employment Agency) for non-automatable tasks they categorize them as: analytical non-routine tasks, interactive non-routine tasks. This model when applied on Germany results in between 15 and 38\% of German employees at risk, other tasks like cognitive routine tasks, manual routine tasks and manual non-routine are subject to automation tasks as illustrated in Table 3 (Dengler, Matthes, \& Wiebke, 2014).

Table 3. Assignment of Activities

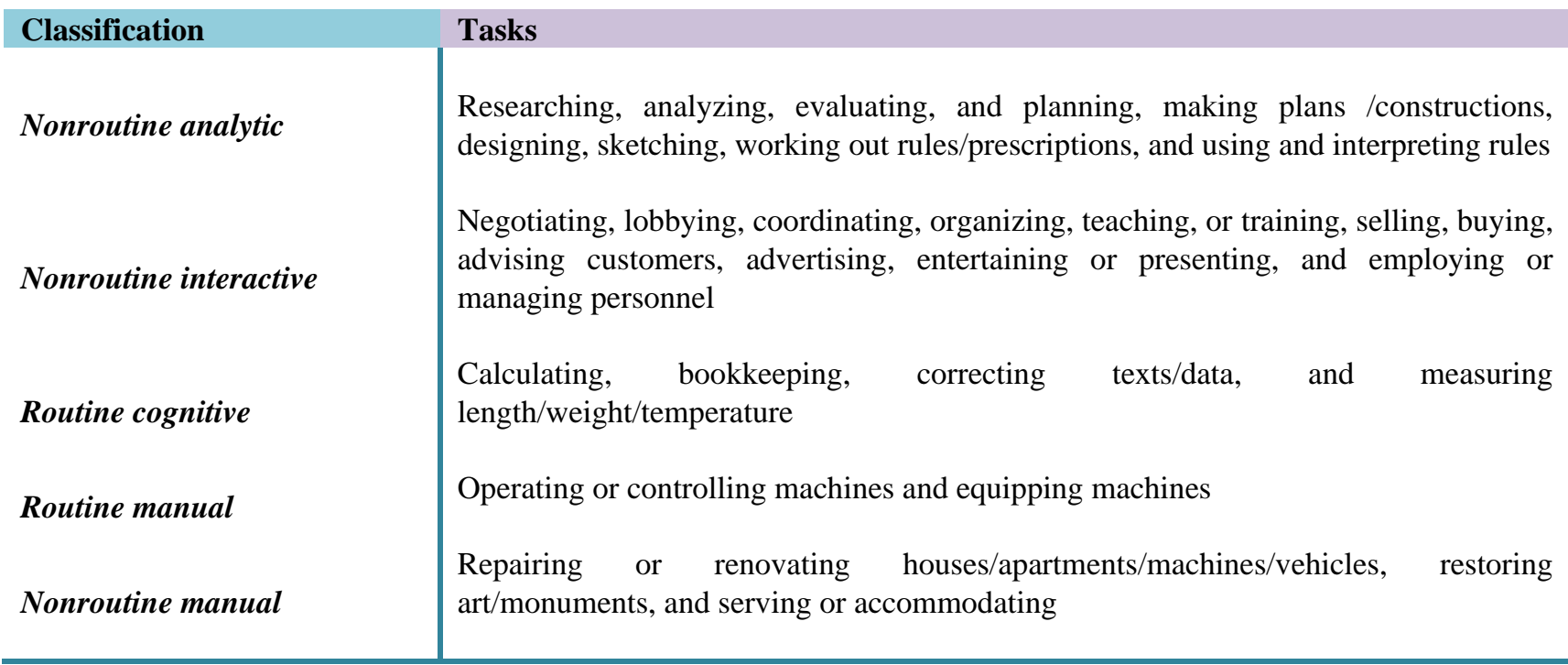

Source: Technical Change, Job Tasks, and Rising Educational Demands: Looking outside the Wage Structure (Spitz-Oener, 2006).

The Impact of Digital Transformation on Regional Labour Markets in Germany: Per Kropp and Katharina Dengler, divided Germany to administrative and manufacturing regions. It was clear that manufacturer regions are prone to automation from health and social services or the hotel and restaurant industry. Additional jobs were created during the introduction of new products and productivity gains from Automation. In many cases positives and negatives cancel each other, Nevertheless the values range between 15 and 38\% (Kropp \& Dengler, 2019).

A-Task Based Approach: A model produced by Melanie Arntz, Terry Gregory, and Ulrich Zierahn. In which they argue that FO Model Ignore that, the occupations consist of many tasks, part of them can be automated and another part cannot be. Also, FO assume that the occupations are the same everywhere, However the task structure is different from place to another. They focus on what people is doing in their job rather than the actual description of the jobs, using individual-level survey data provided by PIAAC (Program for the International Assessment of Adult Competencies). They rely on individual survey data regarding a comprehensive list of tasks that people perform at their workplace. The results of this study revealed that $9 \%$ of USA will be subject to automatability instead of $47 \%$ previously stated by FO. This is because the occupation can contain mix of Automated tasks and hard to automate tasks. In conclusion, Task Based Approach gives lower Estimated of unemployment Risk than FO model (Arntz, Gregory, \& Zierahn, 2016).

Automation Risk in OECD Market: Applying the task-based Approach on The Organization for Economic Co-operation and Development (OECD) using the recently released PIACC database (Program for the International Assessment of Adult Competencies) that surveys task structures across OECD countries. The results that on average OECD countries is $9 \%$ subject to automation (Arntz, Gregory, \& Zierahn, 2016).

Automation Risk in Northern Ireland: Sórcha Foster, and Lisa Wilson, Using the task-based approach indicate that 7\% of Northern Ireland employees will be at high risk of automation and $58 \%$ will be in the risk zone with potential automation over the medium term (Sórcha \& Lisa, 2019). 


\subsubsection{Summary of the Models and Its Application}

Table 4 summarize the previous models and illustrate its application.

Table 4. Summary of the models and its application

\begin{tabular}{|c|c|c|c|}
\hline $\begin{array}{l}\text { Model Name } \\
\text { The Task Model }\end{array}$ & $\begin{array}{l}\text { Authors } \\
\text { David H. Autor, Frank } \\
\text { Levy, and Richard J. } \\
\text { Murnane } \\
2003\end{array}$ & $\begin{array}{l}\text { Description } \\
\text { They argue that computer can do the } \\
\text { following: } \\
\text { 1. Substitutes workers performing } \\
\text { routine tasks by following } \\
\text { programmed sequence and rules. } \\
2 \text {. complements workers } \\
\text { performing nonroutine and complex } \\
\text { tasks (Autor, Levy, \& Murnane, } \\
2003 \text { ). }\end{array}$ & $\begin{array}{l}\text { Application } \\
\text { Was used to generate } \\
\text { FO Model }\end{array}$ \\
\hline $\begin{array}{l}\text { An } \\
\text { Occupation-Based } \\
\text { Approach }\end{array}$ & $\begin{array}{l}\text { Carl Benedikt Frey and } \\
\text { Michael A. Osborne } \\
2013\end{array}$ & $\begin{array}{l}\text { They argue that all the tasks can } \\
\text { Be automated except the tasks which } \\
\text { required certain skills such as they } \\
\text { called then Called them bottlenecks } \\
\text { to computerization: } \\
\text { 1- Perception and Manipulation } \\
\text { tasks: Robots are still unable to } \\
\text { match the depth and breads of human } \\
\text { perception. } \\
\text { 2- Creative intelligence tasks: The } \\
\text { psychological processes underlying } \\
\text { human creativity are difficult to } \\
\text { specify. } \\
3-\text { Social intelligence tasks: Human } \\
\text { social intelligence is important in a } \\
\text { wide range of work tasks such as } \\
\text { those involving negotiation, } \\
\text { persuasion, and care. } \\
\text { These tasks cannot be automated in } \\
\text { the time being however it might in } \\
\text { the future. }\end{array}$ & $\begin{array}{l}\text { Was applied on USA, } \\
\text { on which } 47 \% \text { of its } \\
\text { employment placed in } \\
\text { the high-risk category, } \\
14 \% \text { of EU, } 36 \% \text { of } \\
\text { Spain, } 33 \% \text { of Finland, } \\
25 \% \text { of Singapore. }\end{array}$ \\
\hline $\begin{array}{l}\text { Occupational } \\
\text { Tasks in the } \\
\text { German Labour } \\
\text { Market }\end{array}$ & $\begin{array}{l}\text { Katharina Dengler, } \\
\text { Britta Matthes and } \\
\text { Wiebke Paulus } \\
2014\end{array}$ & $\begin{array}{l}\text { They made new Operationalization } \\
\text { for FO bottlenecks for } \\
\text { non-automatable tasks and categorize } \\
\text { them as: analytical non-routine tasks, } \\
\text { interactive non-routine tasks, } \\
\text { cognitive routine tasks, manual } \\
\text { routine tasks, and manual } \\
\text { non-routine tasks }\end{array}$ & $\begin{array}{l}\text { the values of high risk } \\
\text { of unemployment } \\
\text { range between } 15 \text { and } \\
38 \% \text { depend on the } \\
\text { region type } \\
\text { administrative or } \\
\text { manufacturing, }\end{array}$ \\
\hline $\begin{array}{ll}\text { A-Task } & \text { Based } \\
\text { Approach } & \end{array}$ & $\begin{array}{l}\text { Melanie Arntz, Terry } \\
\text { Gregory, and Ulrich } \\
\text { Zierahn } \\
2015\end{array}$ & $\begin{array}{l}\text { they argue that FO Model Ignore } \\
\text { that, the occupations consist of many } \\
\text { tasks, part of them can be automated } \\
\text { and another part cannot be. Also, FO } \\
\text { assume that the occupations are the } \\
\text { same everywhere, However the task } \\
\text { structure is different from place to } \\
\text { another. They focus on what people } \\
\text { is doing in their job rather than the } \\
\text { actual description of the jobs, using } \\
\text { individual-level survey data provided } \\
\text { by PIAAC }\end{array}$ & $\begin{array}{l}\text { OECD countries is } \\
9 \% \text { subject to } \\
\text { automation. } \\
7 \% \text { of Northern } \\
\text { Ireland }\end{array}$ \\
\hline
\end{tabular}




\subsection{COVID-19}

COVID-19 is acting as a catalyst for change in many fields like economic, societal, personal, and corporate, on a scale not seen before (Fitzpatrick, Gill, Ari Libarikian, Smaje, \& Zemmel, 2020). COVID-19 Also may accelerate Flexible work arrangement and telecommuting (Béland, Brodeur, \& Wright, 2020). There are 3 phases for COVID-19 in which managers should do the following:

1- Navigating the current crisis with resolve and resilience.

2- Planning for the recovery.

3- Reimagining the next normal (Gavin, Harrison, Plotkin, Spillecke, \& Stanley, 2020).

\subsubsection{COVID-19 Effect on Economic}

COVID-19 Cases and deaths will affect the economy directly by the infected and died people and indirectly by the fear which will cause impact on consumers behaviors which turned to be massive consumption in the first days of the lockdown then decreased sharply. COVID-19 may impact the distribution of wealth with the massive demand on medical and pharmaceutical goods (Béland, Brodeur, \& Wright, 2020). There is a direct Impact on each country in the world, include health, lockdowns, and travel restrictions. Indirect impact, closed economy and shifting global value chain.

\subsubsection{COVID-19 Effect on Unemployment}

COVID-19 is expected to decrease $10.5 \%$ of the working hours worldwide in the second quarter of 2020, which equivalent to 305 Million full time-worker (Banga \& Velde, 2020). In USA COVID-19 had a negative impact on unemployment rate about $1 \%$. The most affected group was the less educated workers which increase the inequality. Negative impact was monitored on Entrepreneurship activities. Occupations which was able to work from home was the less affected occupations. Same as the jobs which are more exposed to the disease.

As a result of stay at home the unemployment rate will have a further increase by 3.5 to $4 \%$ which corresponds to from 5.2 to $6 \%$ million additional jobs lost (Béland, Brodeur, \& Wright, 2020).

\subsubsection{COVID-19 Effect on Digital Transformation}

"who is driving your digital transformation. The first two options are CEO and chief digital officer. In this time, it is COVID-19". Based on the change of customer behavior, New consumer groups tried digital products for the first time such as Video Chat to hold their business meetings from home. This is increase also happened in B2B (Fitzpatrick, Gill, Ari Libarikian, Smaje, \& Zemmel, 2020).

As most of the countries around the world enforce a lockdown on its citizens, it creates a huge demand on digital services. Ordering groceries and telemedicine become a norm and hundreds of millions of employees relaying on telecommunication services (mobile\& fixed broadband) as well as collaborative tools to perform their jobs. Studying the new behaviors require attention in several fields to satisfy the customers new needs such as:

1- Serving the customers without touch e.g., QR code reading menus in the restaurants

2- Digitize person interaction services such as renewal of identity cards.

3- Creating incentive for customers to switch to online services.

4- Increase back office application to Smooth WFH.

5- Create Fast application to meet customer demand

6- Working with regulator to authorize new products such as telemedicine.

7- Using cloud computing to ease the development and usage of application (Alatovic, Chhaya, Juneja, Smaje, \& Sukharevsky, 2020).

\subsubsection{COVID-19 and Remote Working}

The Main advice from health specialists and organization is to stay at home (Mendonça \& Dantas, 2020). According to a survey done in USA, resulted in 33\% of the survey respondent had shift to working from home, $10 \%$ was laid-off or furloughed and the rest still commuting. The new approaches which were adopted during the pandemic may involve not only WFH trends, but also could affect the structures of the organizations e.g., the jobs one by remote workers can be offshored to the other countries. jobs which have a mix of tasks can be unbundled to 2 jobs one need interaction with people and the other one can continue work remotely (Brynjolfsson, et al., 2020). Stay at home orders increased the unemployment in USA by additional $4 \%$ and reduced the labor force participation rate by $2.2 \%$ (The proportion of the working-age population that is either working or actively looking for work). Occupation work is proximity to others (Like dentist) are more affected than people were able to work remotely. The order of working from home was cost 
effective, it saves lives and reduce hospitalization costs regardless the loss of income taxes due to unemployment and cancelling of people gathering events like sports, trade shows and festivals (Béland, Brodeur, \& Wright, 2020).

\subsubsection{COVID-19 New Normal}

COVID-19 has imposed a global sense of uncertainty, all the expectations remain theoretical as we do not now the Impact on the careers, one estimates that $42 \%$ of jobs lost will not be returned. The speed of the recovery and how many sectors will be affected overtime is not known. What is known that there will be a change the same as industrial revolutions in which we are living in the $4^{\text {th }}$ one time (Hite \& McDonald, 2020).

An indication from China, 55\% increase in consumers intending to permanently shift to online grocery shopping after the pandemic and increase of 3 to 6 points in overall E-commerce. We assume if the people used to perform activities through a digital platform during the pandemic, they will continue use it which will save a lot for the producers and decrease the cost.

Examples of several trends appear and might be continued:

1. digital banking, the customer uses it during the pandemic in larger scale than before, if continued will save establishing new costly branches.

2. The retail spaces prices have been fallen by $35 \%$ and might also affected after the pandemic.

3. Expectation for shutdown underperforming stores is on the way and replacing them by online stores.

4. New trend under study, buy online and pick from the store.

5. Stores might shift to be a show room only (Diebner, Silliman, Ungerman, \& Vancauwenberghe, 2020).

Four Aspects appear during the COVID-19 if continued it will affect the overall employment in Negative way:

1. Telepresence.

2. Urban de-densification.

3. Employment concentration in large firms.

4. Automation forcing (Autor \& Reynolds, 2020).

Also. The effectiveness of the move towards B2B remote working would encourage the companies to use the same model after the pandemic especially in India and USA in which the effectiveness of remote working survey was rated $68 \%$ and $60 \%$ respectively (Gavin, Harrison, Plotkin, Spillecke, \& Stanley, 2020). The CEO's of the Indian companies decided to use what was learned in COVID-19 and to focus on 3 domains:

1- Digitize sales and consumer experience in both B2C and B2B context. This will let them meet customer expectation while saving sales costs and decrease the physical locations.

2- Digitize their supply chains and manufacturing operations.

3- Establish digital platforms which can serve multiple groups and integrate them in the future to increase their offering (Dhawan, 2020).

\section{Methodology}

Egypt telecommunication market is well prepared and qualified from industrial point of view to be one of the pioneers in Digital Transformation, however it is not confirmed yet if the Digital transformation techniques such as Automation and Artificial intelligent would affect the employment in mobile operators. Thus, it is necessary to predict the effect of Digital transformation as well as the effect of other Important factor which is COVID-19 in which it will act as the catalyst to a digital transformation and will add work/life new techniques.

\section{Dependent variables}

VAR (Y): Unemployment is when a person who is seeking a work to fulfill his needs is unable to find a work.

\section{Independent variable}

VAR (X1): Automation and AI is the use of intelligent machines to perform a tasks or full job was done before by a human being.

\section{Mediating variables}

VAR (Me1): COVID-19 which will act as a catalyst to a digital transformation and will add work/life new techniques which will continue after the pandemic. The new techniques can affect the employment direct and indirect. 


\section{Theoretical Framework}

Figure 12 illustrate the theoretical framework.

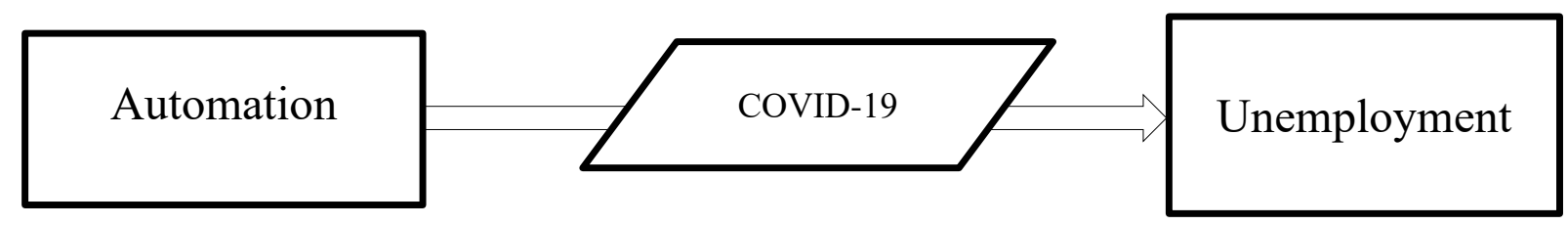

Figure 12. Theoretical Framework

We will use a narrative approach, and we will collect the data through structured interviews to find an answer to the following research questions:

\section{Research Questions}

Major Q (1): To what extent Automation and Artificial intelligence will cause an unemployment in Mobile operators in Egypt?

Minor Q (2): To what extent COVID-19 in Egypt will Mediate the relation between Automation\& Artificial intelligence and unemployment?

\section{Sampling Method}

We will use nonprobability judgmental sample by interviewing 6 HODs in the technology department in one Mobile operator in Egypt who formulate 25\% from the total employment of the Mobile operator under the study.

\section{Data Collection Steps}

1- We will ask the HODs about the contribution of their work force in the below tasks/skill set. and what is the contribution of these from their overall jobs? As illustrated in Table 5.

Table 5. Un-Automatable Skills/Tasks

\begin{tabular}{|c|c|c|c|}
\hline & Tasks/Skills & & Tasks/Skills \\
\hline 1 & $\begin{array}{l}\text { Technical skills } \\
\text { solving Technical problems which required Manual } \\
\text { intervention in limited area spaces and sometimes need } \\
\text { finger dexterity }\end{array}$ & 11 & Customer advisor \\
\hline 2 & $\begin{array}{l}\text { Problem solving skills } \\
\text { Ability to solve problems which occurs for the first time }\end{array}$ & 12 & Doing Research \\
\hline 3 & $\begin{array}{l}\text { Learning skills } \\
\text { Frequent learning and applying of new things }\end{array}$ & 13 & Analyzing Data \\
\hline 4 & Setting up plans & 14 & Constructions of new assets \\
\hline 5 & Managing duties according to plan & 15 & Designing and sketching \\
\hline 6 & Team management & 16 & Software development \\
\hline 7 & Teaching and instructing people & 17 & lobbying with other parties \\
\hline 8 & Making speeches or presentation & 18 & Training people \\
\hline 9 & Selling a product or service & 19 & Doing Advertisement \\
\hline 10 & Negotiation to buy product or service from suppliers & 20 & employing people \\
\hline
\end{tabular}

By answering the above question on the 20 Skills/Tasks mentioned in the table we can calculate the non-automatable tasks contribution from overall tasks. By this we can determine the risk of automation per dept, adding all dept togethers we can determine the risks on the organization.

2- We will ask the Technology HOD's about the effect of COVID-19 on the efficiency created on their team contribution from the 20 tasks/skills this efficiency which should continue after the pandemic will lead to less staff needed in performing the non-automatable skills/tasks which will consider more risks on employment.

The research questions flow diagram is illustrated in figure 13. 


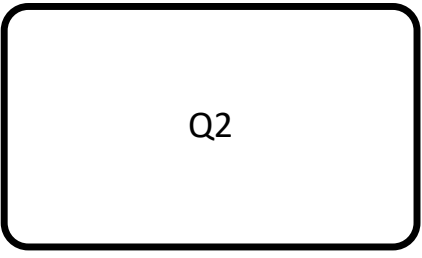

\subsection{Questionnaire}

The New effect on the Unemployment

After COVID-19

Figure 13. Research Questions Flow diagram

1- What is the size of your team?

2- What is the percentage of your team performing one or more of the listed tasks or using these skills to perform certain tasks, and what is the contribution of this tasks from their overall jobs?

3- Was there an increase in performing these tasks during COVID-19?

Table 6 illustrate the questionnaire.

Table 6. Questionnaires

\begin{tabular}{|c|c|c|c|c|}
\hline & \multirow[t]{2}{*}{ Skills } & \multirow{2}{*}{$\begin{array}{l}\text { No } \\
\text { of involved } \\
\text { persons }\end{array}$} & \multirow{2}{*}{$\begin{array}{l}\% \\
\text { Of } \\
\text { their } \\
\text { overall } \\
\text { tasks }\end{array}$} & \multirow{2}{*}{$\begin{array}{l}\text { Efficiency } \% \\
\text { During } \\
\text { COVID-19 }\end{array}$} \\
\hline & & & & \\
\hline 1 & $\begin{array}{l}\text { Technical skills } \\
\text { solving Technical problems which required Manual } \\
\text { intervention in limited area spaces and sometimes need finger } \\
\text { dexterity }\end{array}$ & & & \\
\hline 2 & $\begin{array}{l}\text { Problem solving skills } \\
\text { Ability to solve problems which occurs for the first time }\end{array}$ & & & \\
\hline 3 & $\begin{array}{l}\text { Learning skills } \\
\text { Frequent learning and applying of new things }\end{array}$ & & & \\
\hline 4 & Setting up plans & & & \\
\hline 5 & Managing duties according to plan & & & \\
\hline 6 & Team management & & & \\
\hline 7 & Teaching and instructing people & & & \\
\hline 8 & Making speeches or presentation & & & \\
\hline 9 & Selling a product or service & & & \\
\hline 10 & Negotiation to buy product or service from suppliers & & & \\
\hline 11 & Customer advisor & & & \\
\hline 12 & Doing Research & & & \\
\hline 13 & Analyzing Data & & & \\
\hline 14 & Constructions of new assets & & & \\
\hline 15 & Designing and sketching & & & \\
\hline 16 & Software development & & & \\
\hline 17 & lobbying with other parties & & & \\
\hline 18 & Training people & & & \\
\hline 19 & Doing Advertisement & & & \\
\hline 20 & employing people & & & \\
\hline
\end{tabular}




\section{Results \& Analysis}

To calculate the Automation Risks on the Technology Staff we are following these steps:

1- Calculate the no of people doing un- automatable tasks $\mathrm{Z}=\sum_{\mathrm{n}=1}^{20} \mathrm{Xn} \times \mathrm{Yn}$

Where Xn:Is the No of people doing one of the un-automatable tasks

Where $Y n$ : Is the percentage of the contribution on this task from the overall time of the people involved in this task.

The 20 is the 20 Unautomated Tasks.

2- Calculate the no of people doing Automatable Tasks $\mathrm{K}=\mathrm{M}-\mathrm{Z}$

Where $\mathrm{M}=$ Total No of employees

3- Calculate the Risk from Automation R1 $=\mathrm{k} \div \mathrm{M}$

The results of the risks on 6 technological department having 25\% from the mobile Operator Manpower is illustrated in Table 7 and Table 8 .

Table 7. Automation Risk on Different Technology Departments in Mobile Operators

\begin{tabular}{lllllll}
\hline & Tech1 & Tech2 & Tech3 & Tech4 & Tech5 & Tech6 \\
\hline Risk from Automation & $\mathbf{2 0 . 2 7 \%}$ & $\mathbf{5 7 . 0 4 \%}$ & $\mathbf{5 1 . 2 0 \%}$ & $\mathbf{2 1 . 0 0 \%}$ & $\mathbf{4 1 . 0 0 \%}$ & $\mathbf{1 6 . 9 8 \%}$ \\
\hline Table 8. Automation Risk on Technology Departments in Mobile Operators & & & \\
\hline
\end{tabular}

To calculate the Incremental Additional Risks on the Technology Staff from the efficiency created through WFH which was widely spread because of COVID-19.

1- Calculate the no of manpower can be added on the unautomated tasks as

$$
\mathrm{C}=\sum_{n=1}^{20} X n \times V n
$$

Where $X n$ : Is the No of people doing one of the un-automatable tasks

Where $V n$ : Is the percentage of the additional efficiency added to the overall time of the people involved in this task.

The 20 is the 20 Unautomated Tasks.

2- Calculate the Risk from COVID-19 R2 $=\mathrm{C} \div \mathrm{M}$

The results of the COVID-19 risk on 6 technological department are illustrated in Table 9.

Table 9. COVID-19 Risk on Different Technology Departments in Mobile Operators

\begin{tabular}{lllllll}
\hline & Tech1 & Tech2 & Tech3 & Tech4 & Tech5 & Tech6 \\
\hline Incremental Risk from COVID-19 & $\mathbf{2 . 3 5 \%}$ & $\mathbf{1 0 . 0 0 \%}$ & $\mathbf{- 0 . 3 0 \%}$ & $\mathbf{2 3 . 8 3 \%}$ & $\mathbf{1 3 . 6 6 \%}$ & $\mathbf{9 . 8 4 \%}$ \\
\hline
\end{tabular}

Incremental Risks from COVID-19 on the Technology Department is illustrated in Table 10.

Table 10. COVID-19 Risk on Technology Departments in Mobile Operators

\begin{tabular}{lc}
\hline Incremental Total Risk from COVID-19 & $8.46 \%$
\end{tabular}

The Total Risks from the Automation and COVID-19 is illustrated in Table 11.

Table 11. Total Unemployment Risk on Technology Departments in Mobile Operators

\begin{tabular}{ll}
\hline Risk from Automation & $41.23 \%$
\end{tabular}

The Incremental Risk from COVID-19 $\quad 8.46 \%$

$\begin{array}{ll}\text { Total Risk } & 49.69 \%\end{array}$

To calculate the Automation Risks on Un-automatable tasks:

Number of manpower added because of WFH

$$
\mathrm{T}=\sum_{n=1}^{6} X n \times V n
$$

Where $X n$ : Is the No of people doing one of the un-automatable tasks

Where $V n$ : Is the percentage of the additional efficiency added to the overall time of the people involved in this task.

The 6 is the No of the Technology teams. 
The most affective tasks are illustrated in Table 12 and the least affected one is illustrated in Table 13.

Table 12. Most affected tasks because of COVID-19

\begin{tabular}{ll}
\hline Task & COVID-19 Risk \\
\hline Software development & $24 \%$ \\
Learning & $30 \%$ \\
Setting up plans & $37 \%$ \\
Problem solving & $53 \%$ \\
Analyzing Data & $56 \%$ \\
\hline
\end{tabular}

Only one task was negatively affected due to WFH as the presence is more efficient than working from home.

Table 13. Negatively affected tasks because of COVID-19

\begin{tabular}{ll}
\hline Task & $\%$ Of Risks \\
Teaching and instructing people & $-112 \%$ \\
\hline
\end{tabular}

\section{Conclusion}

$41 \%$ of the Technology staff in the Mobile operators will be on Risk of unemployment because of the Digital Transformation. COVID-19 will add another $8 \%$ Risk, as certain un-automatable tasks when performed from home during COVID-19 was performed better, which can create efficiencies and reduce the no of people performing these tasks. COVID-19 through WFH creates more efficiency on the following tasks: Analyzing Data 56\%, Problem solving $53 \%$, Setting up plans $37 \%$, Learning skills $30 \%$ and Software development $24 \%$. This is does not mean a total reduction in their jobs as their jobs constitutes of many tasks. Only one tasks all the participant agreed that it had a negative effect when performed from home which was Teaching and instructing people.

\section{Recommendation}

As the change is fact of life and we are facing a hyper technological change unprecedented in the human history. People should struggle more to keep their jobs by continuous learning and acquiring an un-automatable skills to remain employed.

\section{Further Research}

Study and Quantify, Other factors which can mitigate the effect of the Digital Transformation practices which was accelerated by COVID-19 on the Employment such as Reskilling and Upskilling, Introducing new product and services as well as the creation of a complementary tasks.

\section{References}

Alatovic, T., Chhaya, M., Juneja, S., Smaje, K., \& Sukharevsky, A. (2020, April). Driving digital change during a crisis: The chief digital officer and COVID-19. McKinsey.

Arntz, M., Gregory, T., \& Zierahn, U. (2016, May 13). The Risk of Automation for Jobs in OECD Countries: AComparative Analysis. Paris, France: OECD Social, Employment and Migration Working Papers.

Autor, D. H. (2015). Why Are There Still So Many Jobs? The History and Future of Workplace Automation. Journal of Economic Perspectives, 29(3), 3-30. https://doi.org/10.1257/jep.29.3.3

Autor, D. H., Levy, F., \& Murnane, R. J. (2003, June). The Skill Content Of Recent Technological Change: An Empirical exploration. Quarterly Journal of Economics, 118(4), 1279-1333. https://doi.org/10.1162/003355303322552801

Autor, D., \& Reynolds, E. (2020, July 14). The Nature of Work after the COVID Crisis: Too Few Low-Wage Jobs. The Hamilton Project.

Banga, K., \& Velde, D. W. (2020, July). Cambodia, COVID-19 and inclusive digital transformation: a seven-point plan.

Béland, L.-P., Brodeur, A., \& Wright, T. (2020, April). The Short-Term Economic Consequences of COVID-19: Exposure to Disease, Remote Work and Government Response. Bonn, Germany.

Béland, L.-P., Brodeur, A., \& Wright, T. (2020, May). COVID-19, Stay-At-Home Orders and Employment: Evidence from CPS Data.

Bessen, J. (2016, October). How Computer Automation Affects Occupations: Technology, jobs, and skills. Boston: Boston University School of Law. https://doi.org/10.2139/ssrn.2690435 
Bonekamp, L., \& Sure, M. (2015). Consequences of Industry 4.0 on Human Labour and Work Organisation. Journal of Business and Media Psychology, 6(1), 33-40.

Brynjolfsson, E., \& Andrew, M. (2014). The Second Machine Age. London: W. W. Norton \& Company.

Brynjolfsson, E., Horton, J. J., Ozimek, A., Rock, D., Sharma, G., \& TuYe, H.-Y. (2020, June). COVID-19 and Remote Work: An Early Look at US Data. https://doi.org/10.3386/w27344

Cedfop (European Center for the Development of Vocational Training). (2017, July). People, Machines, Robots and Skills. Greece.

Csefalvay, Z. (2019, 2). What are the policy options? A systematic review of policy responses to the impacts of robotisation and automation on the labour market. JRC.

Deloitte. (2020). Understanding The Sector impact of COVID-19 Telecommunication.

Dengler, K., Matthes, B., \& Wiebke, P. (2014, Dec). Occupational Tasks in the German Labour Market. FDZ method reports.

Dhaka, R. S. (1998, Dec 31). Schemes and Implementation of Employment Programmes in Haryana: A case study of Rohtak District. India.

Dhawan, R. (2020, July). Five priorities for corporate India in the next normal after COVID-19. Mckinsey\& Company.

Diebner, R., Silliman, E., Ungerman, K., \& Vancauwenberghe, M. (2020, April). Adapting customer experience in the time of coronavirus. Mckinsey.

Doménech, R., García, J. R., Montañez, M., \& Neut, A. (2017). How vulnerable is Spanish employment to the digital revolution? Madrid, Spain: BBVA Research .

Egypt Vision 2030. (2016). Retrieved from http://mcit.gov.eg/Publication/Publication_Summary/1020/

Elsafty, A. (2018). Business Research Methods. Egypt: Lecture Notes, Lecture One.

Elsafty, A. (2018). Lecture 2: Scientific Business Research Problem Definition [PowerPoint slides]. Retrieved from Maastricht School of Management, MBA Degree.

Elsafty, A. (2018). Lecture 2: Scientific Business Research Problem Definition [Lecture]. Retrieved from Maastricht School of Management, MBA Degree.

Elsafty, A. (2020). DrAshrafElsafty Channel. Retrieved from Youtube: https://www.youtube.com/watch?v=y-jDT2iOOhU\&list=PLKSWZdnzp8p3uFLLh2N8_d0W7ZmJDLMjW\&index= $42 \& \mathrm{t}=628 \mathrm{~s}$

Elsafty, A., \& AlNawaly, A. (2020). Role of Co-Working Spaces' Services in Entrepreneurs Growth in Upper Egypt, The Case of Step Co-Working Space. Business and Management Studies, 6(2), June 2020. ISSN: 2374-5916 E-ISSN: 2374-5924. https://doi.org/10.11114/bms.v6i2.4898

Elsafty, A., \& Ragheb, M. (2020). Role of Human Resource Management towards Employees Retention during Covid-19 Pandemic. Business and Management Studies, 6(2), June 2020. ISSN: 2374-5916 E-ISSN: 2374-5924. https://doi.org/10.11114/bms.v6i2.4899

Elsafty, A., Abadir, D., \& Shaarawy, A. (2020). How Does the Entrepreneurs' Financial, Human, Social and Psychological Capitals Impact Entrepreneur'S Success?. Business and Management Studies, 6(3), 55-71. https://doi.org/10.11114/bms.v6i3.4980

Elsafty, A., Elbouseery, I., \& Shaarawy, A. (2020). Factors Affecting the Behavioral Intention to Use Standalone Electronic Personal Health Record Applications by Adults in Egypt. Business and Management Studies, 6(4), 14-36. https://doi.org/10.11114/bms.v6i4.5066

Elsafty, A., Elsayed, H., \& Shaaban, I. (2020), A Business Analysis Perspective for Engineering Education in Egypt. Journal of Education and Training Studies, 8(5), May 2020. ISSN 2324-805X E-ISSN 2324-8068. https://doi.org/10.11114/jets.v8i5.4721

Elsafty, A., Elsayed, H., \& Shaaban, I. (2020). Educating Engineering Students in Egypt: Recommendations for Improvement. International Journal of Higher Education. https://doi.org/10.5430/ijhe.v9n3p1

Elsafty, A., Elsayed, H., \& Shaaban, I. (2020). Journal of Education and Training Studies, 8(8), August 2020. ISSN 2324-805X E-ISSN 2324-8068. https://doi.org/10.11114/jets.v8i8.4901

Fitzpatrick, M., Gill, I., Ari Libarikian, Smaje, K., \& Zemmel, R. (2020, April). The digital-led recovery from COVID-19: Five questions for CEOs. McKinsey \& Company. 
Forum, W. E. (2018). The Future of Jobs Report. Geneva: World Economic Forum.

Frey, C. B., \& Osborne, M. A. (2013, September 17). The Future of Employment. Oxford, England: Oxford Martin Programme on Technology and Employment.

Fuei, L. K. (2017, July 3). Automation, Computerisation and Future Employment in Singapore.

Gavin, R., Harrison, L., Plotkin, C. L., Spillecke, D., \& Stanley, J. (2020, April). The B2B digital inflection point: How sales have changed during COVID-19. Mckinsey.

Henke, N., Puri, A., \& Saleh, T. (2020, May). Accelerating analytics to navigate COVID-19 and the next normal. Mckinsey.

Hite, L. M., \& McDonald, K. S. (2020, July 13). Careers after COVID-19: challenges and changes. Taylor \& Francis Online. https://doi.org/10.1080/13678868.2020.1779576

IFC. (2020). COVID-19's Impact on the Global Telecommunications Industry.

Kropp, P., \& Dengler, K. (2019). The Impact of Digital Transformation on Regional Labour Markets in Germany: Substitution Potentials of Occupational Tasks. Challenges of Digital Inequality - Digital Education, Digital Work, Digital Life, 1-8. Retrieved from www.ssoar.info

Lokhandwala, S., \& Gautam, P. (2020, June 18). Indirect impact of COVID-19 on environment: A brief study in Indian context, India. https://doi.org/10.1016/j.envres.2020.109807

Mankiw, N. G. (2003). Principles Of Economics. South-Western.

Mckinsey. (2017). jobs lost, jobs gained: workforce transitions in a time of automation. Mckinsey Global Institute.

Mckinsey. (2019). Telecom operators: Surviving and thriving through the next downturn.

McKinsey. (2020). Critical communications infrastructure and COVID-19: An interview with Ericsson's CEO.

Mckinsey. (2020, Sept). Economic Conditions Snapshot, September 2020: McKinsey Global Survey results.

Mendonça, F. M., \& Dantas, M. A. (2020, June 24). Covid-19: Where is the Digital Transformation, Big Data, Artificial Intelligence and Data Analytics? Revista do Serviço Público, Brazil. https://doi.org/10.21874/rsp.v71i0.4770

Min Xu, J., David, M., \& Kim, S. H. (2018, March 8). The fourth Industrial Revolution: Opportunities and Challenges. International Journal of Financial Research, 9(2), 90-95. https://doi.org/10.5430/ijfr.v9n2p90

Nordhaus, W. D. (2015, September). Are We Approaching an Economic Singularity? Information Technology and the Future of Economic Growth. Cambridge, England: Nber Workin Paper Serie. https://doi.org/10.3386/w21547

Pajarinen, M., \& Rouvinen, P. (2014, Jan 13). Computerization Threatens One Third of Finnish Employment. Finland: ETLA The Research Institute of the Finnish Economy.

Pouliakas, K. (2018, September). Determinants of Automation Risk in the EU Labour Market: A Skills-Needs Approach. 11829. Bonn, Germany: IZA Institute of Labor Economics.

Prisecaru, P. (2016). Challenges of The Fourth Industrial Revolution. Knowledge Horizons - Economics, 8(1), 57-62.

Schwab, K. (2016, Jan 14). The Fourth industrial Revolution: what it means, how to respon. World Economic Forum.

Sórcha, F., \& Lisa, W. (2019, February). The Future of Work: The impact of automation technologies for employment in Northern Ireland. Dublin, Northern Ireland: Nevin Economic Research Institute.

Spitz-Oener, A. (2006). Technical Change, Job Tasks, and Rising Educational Demands: Looking outside the Wage Structure. Journal of Labor Economics, 24(2), 235-270. https://doi.org/10.1086/499972

Stevenson, B. (2020, July). The Initial Impact of COVID-19 on Labor Market Outcomes Across Groups and the Potential for Permanent Scarring.

Trannet, M. (n.d.). Egyptian Labor Law. Retrieved from HG.org Legal Resources: https://www.hg.org/legal-articles/egyptian-labor-law-31577

WorldBank, T. (2019). Egypt's Economic Update - October 2019.

\section{Copyrights}

Copyright for this article is retained by the author(s), with first publication rights granted to the journal.

This is an open-access article distributed under the terms and conditions of the Creative Commons Attribution license which permits unrestricted use, distribution, and reproduction in any medium, provided the original work is properly cited. 